\title{
THE CONTEXT OF PRODUCTION OF THE VATICAN MANUSCRIPT OF THE SYRIAC LIFE OF SYMEON THE STYLITE
}

\author{
DINA BOERO
}

UNIVERSITY OF SOUTHERN CALIFORNIA

\begin{abstract}
This article identifies the place and institutional context of production of Vatican Syriac Manuscript 160, ff. 1-79. It argues that the priest Simeon of Marimin and the archdeacon Cyrus oversaw the production of the Vatican manuscript's version of the Syriac Life of Symeon the Stylite as well as the construction of a hostel (pandocheion) in Telneshe in the 470s. The two expenditures were part of a broader project of promoting pilgrimage to Symeon's cult site. Since this manuscript contains either the autograph or an extraordinarily early version of the Syriac Life of Symeon, locating the manuscript's place and institutional context of production clarifies the rhetorical project of this manuscript's version of the Syriac Life of Symeon. In addition, the Vatican manuscript represents our fifth earliest dated Syriac manuscript. A sound assessment of the manuscript's place of production contributes to our understanding of fifth-century Syriac paleography, orthography, and manuscript production. Finally, this article provides an early case in which the composition of a saint's life is clearly connected with the economic organization that characterizes a saint's cult.
\end{abstract}




\section{INTRODUCTION}

Three hagiographies recount the life of Symeon the Stylite the Elder (ca. 385-459). Theodoret, writing between 440 and 444, included a chapter on Symeon in his History of the Monks of Syria. ${ }^{1}$ The Syriac Life of Symeon the Stylite also gives an account of Symeon's life; the version recorded in Vatican Syriac Manuscript 160, ff. 1-79, was composed in 473, approximately thirty years after Theodoret's narrative. $^{2}$ An otherwise unknown individual named Antonius

I presented a version of this paper at Hugoye Symposium III: Colophons in the Syriac Tradition. I thank Kevin van Bladel, Andrew Faulkner, Christelle Fischer-Bovet, Claudia Rapp, Claudia Moatti, Susan Ashbrook Harvey, and Andrea Barrales-Hall for commenting upon early drafts of this article. I also thank the reviewers for their suggestions to improve the article. All errors and oversights are my own.

${ }^{1}$ Pierre Canivet and Alice Leroy-Molinghen, eds. and trans., Histoire des moines de Syrie: Histoire Philothée, Sources Chrétiennes 234 and 257 (Paris: Éditions du Cerf, 1977). For the chapter on Symeon, see vol. 2, 158-214.

2 Two versions of the Syriac Life of Symeon are currently available to scholars. Vatican Syriac Manuscript 160, ff. 1-79, preserves a version dating to 473. Stefano Evodio Assemani transcribed this manuscript in Acta Sanctorum Martyrum Orientalium et Occidentalium: In Duas Partes Distributa. Adcedunt Acta S. Simeonis Stylitae. Omnia Nunc Primum ... E Bibliotheca ... Vaticana Prodeunt, pars II (Romae: J. Collini, 1748), 268-398. Doran translated it into English in Robert Doran, ed. and trans., The Lives of Simeon Stylites, Cistercian Studies Series 112 (Kalamazoo, Mich.: Cistercian Publications, 1992), 101-198. Paul Bedjan transcribed a sixthcentury version of the Syriac Life found in British Library Additional Manuscript 14484, ff. 48-133, in Acta Martyrum et Sanctorum, vol. 4 (Parisiis and Lipsiae: Harrassowitz, 1890), 507-644. Heinrich Hilgenfeld published a German translation of this version in Hans Lietzmann et al., Das Leben des Heiligen Symeon Stylites, TU (Leipzig: J. C. Hinrichs, 1908), 81-180. Frederick Lent published an English translation in "The Life of St. Simeon Stylites: A Translation of the Syriac Text in Bedjan's Acta Martyrum et Sanctorum, Vol. iv" (JAOS 35 [1915]), 103-198. An edition and French translation of a third version of the Syriac Life of Symeon found in Syrian Orthodox Patriarchate at Damascus Manuscript 12/17, ff. 52b$71 \mathrm{~b}$, (twelfth-thirteenth century) and Syrian Orthodox Church of the Forty Martyrs at Mardin Manuscript 271/8, ff. 250-420, (twentieth century) is forthcoming. Georges Bohas et al., ed. and trans., Vie de Syméon le Stylite, Sources Chrétiennes (Paris: Editions du Cerf, forthcoming). The following pages make a case for the primacy of the version found in the Vatican Manuscript. For an evaluation of the eight known Syriac 
wrote a third biography in Greek, sometime in the sixth or seventh century. ${ }^{3}$ Although the Syriac Life of Symeon is not the earliest account of Symeon's life, it is nevertheless important for understanding Symeon and his cult. The Syriac hagiography offers a nearly contemporary witness to Symeon and the earliest account of the final fifteen to twenty years of his life. It is the longest and most detailed of the three hagiographies; the only hagiography written from the perspective of Syriac Christianity, the ascetic tradition from which Symeon emerged; and the only hagiography closely associated with the cult site in Telneshe, a case made in this article. ${ }^{4}$

In addition, whereas the earliest manuscripts of Theodoret's and Antonius' hagiographies date to the ninth and tenth centuries respectively, the 473 date of the Vatican manuscript is extraordinarily early. ${ }^{5}$ Vatican Syriac Manuscript 160, ff. 1-79, is the

manuscripts and one of the four known Georgian manuscripts, see Dina Boero, "Symeon and the Making of the Stylite" (PhD diss., University of Southern California, forthcoming 2015).

3 An edition of this text can be found in Lietzmann, Das Leben des Heiligen Symeon Stylites, 20-78. Doran published an English translation in Doran, Lives, 85-100. Mayer and Allen date the life to the sixth or seventh century based on the mention of the Church of Cassian at Antioch at the close of the narrative. The earliest witness to the existence of the Church of Cassian is a homily of Severus of Antioch delivered in 513. The Church of Cassian is one of only two churches from Late Antiquity that continued to thrive into the eleventh century. Thus, the text must date to the sixth century or some later date. Wendy Mayer and Pauline Allen, The Churches of Syrian Antioch (300-638 CE), Late Antique History and Religion 1 (Leuven: Peeters, 2012), 106-107.

${ }^{4}$ Harvey highlights the broader tradition of Syriac Christianity on which the Syriac Life of Symeon builds. Susan Ashbrook Harvey, "The Sense of a Stylite: Perspectives on Simeon the Elder" (VChr 42 [1988]), 376-94. Indeed, while Theodoret visited the cult site and appears to have had access to some archival material there, he does not give a version of Symeon's life from the perspective of his local cult-keepers. On potential archival material from Telneshe to which Theodoret had access, see André-Jean Festugière, Antioche païenne et chrétienne; Libanius, Chrysostome et les moines de Syrie, BÉFAR, Fasc. 194 (Paris: E. de Boccard, 1959), 354-356.

${ }^{5}$ Canivet and Leroy-Molinghen, Histoire des moines de Syrie, vol. 1, 5859; Lietzmann, Das Leben des Heiligen Symeon Stylites, 200-211. 
fifth earliest dated Syriac manuscript in existence. ${ }^{6}$ Certainly, it is the earliest surviving manuscript of the Syriac Life of Symeon the Stylite. Dating only fourteen years after the saint's death, it may even be one of the few autographs of a text to survive from the ancient Mediterranean world. ${ }^{7}$ The early date of the manuscript makes it valuable not only to scholars interested in Symeon the Stylite but also to scholars of early Syriac paleography, orthography, and manuscript production. Given the importance of this manuscript to the textual history of the Syriac Life of Symeon and Syriac manuscript studies more broadly, the location and institutional context of its production deserve precise assessment.

Previous scholars have unanimously asserted that the author of the Syriac Life of Symeon composed his text at or close to Telneshe, the village adjacent to Symeon's cult site in northern Syria [figs. 1 and 2]. Since the author of the text does not explicitly state the place of composition, scholars have made this assertion based on the text's narrative details. Thus, Peeters argues that the Vatican manuscript was composed in Telneshe based on the precise

${ }^{6}$ For catalogue entries on this manuscript, see Giuseppe Simone Assemani, BibOr I (Romae: Typis Sacrae Congregationis de Propaganda Fide, 1719), 235-253, 606; Stefano Evodio Assemani and Joseph Simonius Assemani, Bibliothecae Apostolicae Vaticanae Codicum Manuscriptorum Catalogus in Tres Partes Distributus in Quarum Prima Orientales in Altera Graeci in Tertia Latini Italici Aliorumque Europaeorum Idiomatum Codices, pt. 1, vol. 3 (Paris: Maisonneuve, 1756-1759), 319-324. The manuscript is listed as the fifth oldest dated Syriac manuscript in William Henry Paine Hatch, An Album of Dated Syriac Manuscripts, Monumenta Palaeographica Vetera, 2d Ser. (Boston: American Academy of Arts and Sciences, 1946), 56, pl. 5. In its current state, the Syriac Life is bound together with two other manuscripts, ff. 80-219 and ff. 220-239, which both contain lives of martyrs. Assemani and Assemani, Bibliothecae Apostolicae Vaticanae, pt. 1, vol. 3, 324. Brock dates ff. 80-219 to the sixth century. Sebastian P. Brock, The History of the Holy Mar Ma'in with a Guide to the Persian Martyr Acts, Persian Martyr Acts in Syriac: Text and Translation (Piscataway, NJ: Gorgias Press, 2008), 88. To my knowledge, the handwriting of ff. 220-239 has not received close scrutiny.

7 Peeters makes a case that this manuscript is the autograph of the text. Paul Peeters, Le tréfonds oriental de l'hagiographie Byzantine, SubsHag (Bruxelles: Société des Bollandistes, 1950), 113-121. This issue is discussed with greater detail in the first section of this article. 
topographical details included in the text. ${ }^{8}$ Other scholars have gone further, asserting not only Telneshe as the location of the text's composition but also claiming the institutional context of production. Leitzmann notes that at least some of the sources of the Syriac Life came from a monastery at Telneshe. ${ }^{9}$ Lent and Flusin propose that one of Symeon's disciples in Telneshe wrote the Syriac Life. ${ }^{10}$ Delehaye comments that monks at Telneshe composed the Syriac Life. ${ }^{11}$ Doran argues that the text sets forth the supremacy of the monastery at Qal'at Sem'an over and above the monastery in Telneshe. ${ }^{12}$ Harvey states that the text was written by Symeon's disciples, but also cogently observes a set of distinctly ecclesiastical interests represented in the text. ${ }^{13}$

This article sheds new light on this problem by approaching the manuscript as an artifact of cult life to be read in dialogue with the archaeological evidence surviving from the fifth-century cult site. It compares epigraphic evidence from Telneshe with details provided in the colophon of the Vatican manuscript. Although archaeologists and epigraphers have analyzed extensively the inscriptions of Telneshe and textual scholars have studied the manuscript's contents with care, both sets of scholars have not brought these two bodies of evidence into dialogue with one another in regards to this issue. Using both types of evidence, this article confirms Peeters' assertion that the manuscript was composed in Telneshe, while proposing a context of production distinct from Symeon's community of disciples or the monastic community in Telneshe. It argues that the priest Simeon and the archdeacon Cyrus, two individuals named in the colophon,

${ }^{8}$ Ibid.

${ }^{9}$ Lietzmann, Das Leben des Heiligen Symeon Stylites, 218-219.

10 Lent, "The Life of St. Simeon Stylites," 110; Bernard Flusin, "Syméon et les philologues ou la mort du stylite," in Les saints et leur sanctuaire à Byzance: textes, images et monuments, ed. Catherine Jolivet-Lévy et al. (Paris: Publications de la Sorbonne, 1993), 1.

${ }^{11}$ Hippolyte Delehaye, Les Saints Stylites, SubsHag 14 (Bruxelles and Paris: Société des Bollandistes and A. Picard, 1923), iix. In his assessment of the manuscripts, Delehaye follows Lietzmann.

${ }^{12}$ Doran, Lives, 54.

${ }^{13}$ Susan Ashbrook Harvey, "The Sense of a Stylite," 381 and "The Stylite's Liturgy: Ritual and Religious Identity in Late Antiquity" (JEChrSt 6:3 [1998]), 523-539. 
sponsored the writing of the Vatican manuscript in a church in Telneshe. However, the epigraphic evidence provides further context for the composition of the Vatican manuscript. At the same time that the priest Simeon and the archdeacon Cyrus oversaw the composition of the manuscript, they were also responsible for building a hostel (pandocheion) in Telneshe. Thus, the manuscript and the pandocheion were part of a broader project promoting pilgrimage to the site.

This article establishes the context of production for one of the earliest Syriac manuscripts, takes a small step towards more fully integrating the abundant archaeological evidence of the Limestone Massif with our numerous late antique Syriac manuscripts, and provides an early case in which the composition of a saint's life is clearly connected with the economic organization that characterizes a saint's cult. The first part of this article takes a close look at the authorship and institutional context of production, as evidenced in the manuscript's colophon. The second part analyzes the inscriptions which make it possible to place the manuscript in Telneshe and associate the composition of the manuscript with the construction of pilgrimage infrastructure.

\section{VATICAN SYRIAC MANUSCRIPT 160, FF. 1-79, AND ITS COLOPHON}

The starting point for understanding the production of the Vatican manuscript is the colophon, which introduces the cast of characters involved in its composition.

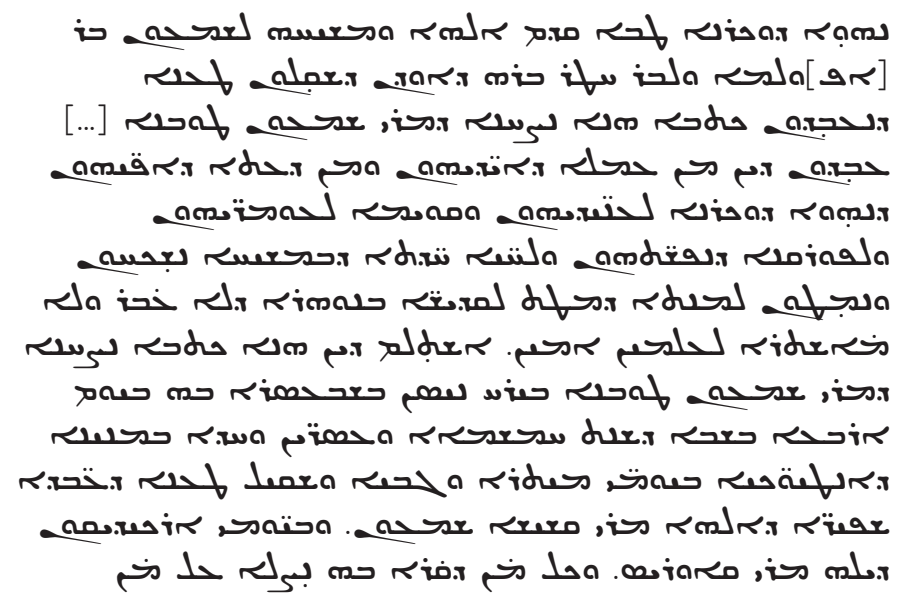




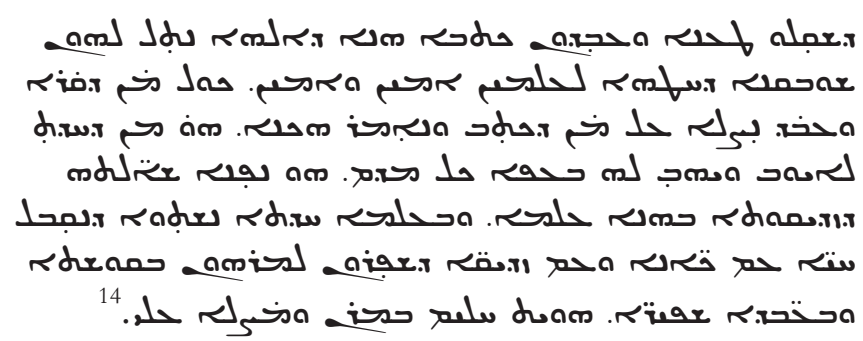

Let this be a good remembrance before God and his Christ for Simeon bar-Eupolemos and bar-Hațar, son of Udan, who undertook to compose this book of the heroic exploit of blessed Mar Symeon [...] They composed it by the toil of their hands and the sweat of their brows so that it be a remembrance for their departed [relatives] and sustenance in their way of life, that they find redemption for their souls and new life in Christ, and that they gain that portion allotted to the saints in the permanent and inextinguishable bright light forever. Amen. This book of the heroic exploit of the blessed Mar Symeon was finished on the seventeenth day of the month Nisan, on the fourth day of the week, in the year five hundred and twenty-one according to the Antiochene reckoning. [It was done] in the time of the excellent and eminent doer of God's good deeds, the priest Mar Simeon, and in the time of his archdeacon Mar Cyrus. Let everyone who reads this pray for those who undertook to compose this book that God may grant them forgiveness of sin forever. Amen. Amen. Let everyone who reads and does this pray for the one who wrote it out. Let him speak thus, 'May $\mathrm{He}$ who revived Job and gave him double of everything answer the request for righteousness in this world and that, in the world to come, we may be worthy to receive life with the just and the righteous who pleased their Lord in truth and

14 Assemani, Acta Sanctorum Martyrum Orientalium, vol. 2, 398.3-34; Vatican Syriac Manuscript 160, ff. 79a-b. In places where Assemani's transcription differs from the manuscript, I follow the manuscript. At 79b.1.5, the second half of the line has been intentionally erased. I have indicated this erasure with the following symbol: [...]. 
good deeds.' May you be firm in the Lord, and pray for me. ${ }^{15}$

First, the colophon introduces two individuals, Simeon barEupolemos and bar-Hațar, son of Udan. The name Simeon barEupolemos requires comment, since my reading of the manuscript differs from previous commentators. Rather than is r ra[a], 'Simeon bar-Eupolemos,' as I have transcribed and translated above, Assemani transcribed rasar, 'Simeon bar-Apollo.'16 To my knowledge, all subsequent commentators have followed Assemani's reading. ${ }^{17}$ Due to damage to the manuscript, the initial allap and $p \bar{e}$ are unclear, although I agree with Assemani's interpretation of the manuscript on this point. However, without a doubt the final two letters of the name are mim and älap, rather than wäw and nun as Assemani transcribed. ${ }^{18}$ Probably, this name is a Syriac rendering of the

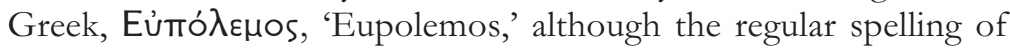
the name in Syriac is ooselanar. ${ }^{19}$

Next, Simeon bar-Eupolemos and bar-Hatar state that they composed the text "by the toil of their hands and the sweat of their

15 I have slightly adapted Doran's translation. Doran, Lives, 197-198.

16 Assemani, Acta Sanctorum Martyrum Orientalium, vol. 2, 398.5.

17 William Wright, A Short History of Syriac Literature (London: A. and C. Black, 1894), 56 n3; Charles C. Torrey, "The Letters of Simeon the Stylite," (JAOS 20 [1899]), 274-275; Peeters, Le tréfonds oriental, 113; Doran, Lives, 197. Although Nöldeke inspected the Vatican Manuscript, he did not comment on the name of the scribes. Theodor Nöldeke, Sketches from Eastern History, trans. J. Sutherland Black (London and Edinburgh: A. and C. Black, 1892), $225 \mathrm{n} 1-2$. Hatch incorrectly stated that the name of the scribe or scribes is not given. Hatch, Album, $56 \mathrm{n} 4$.

${ }^{18}$ I thank George Kiraz, Thomas Carlson, and Sebastian Brock for inspecting this line of the manuscript. All concluded that

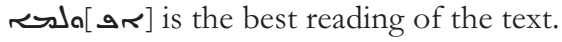

19 R. Payne Smith et al., Thesaurus Syriacus, vol. 1 (Oxonii: e typographeo Clarendoniano, 1879), 85. I thank Sebastian Brock for suggesting the name, 'Eupolemos.' Alternatively, raslar may refer to 'Apulma' or something similar, but such a name is otherwise unattested. Of course, the names 'Hațar' and 'Udan' are not well-attested names either. Thus, the unattested 'Apulma' is not outside the realm of possibility. Nevertheless, Brock's suggestion seems to be the best interpretation. 
brows." In a formulaic manner, they explain that they composed their text for the remembrance of their departed relatives, for the redemption of their souls, for the forgiveness of their sins, and in hopes of prayers spoken aloud by future readers. The specific

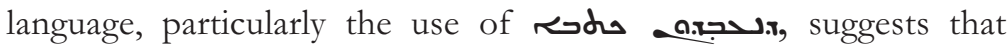
these two individuals were both the scribes and the authors of the manuscript. The colophon also provides the date when the composition was completed: the seventeenth day of Nisan, 521 of the Antiochene calendar, or April 17, 473 CE. Finally, the colophon praises two additional individuals, the priest Mar Simeon and the archdeacon Cyrus, presumably the leaders of the church in which Simeon bar-Eupolemos and bar-Hațar composed their manuscript. This section first addresses the role of Simeon barEupolemos and bar-Hațar and then turns to the priest Mar Simeon and the archdeacon Cyrus.

The role of Simeon bar-Eupolemos and bar-Hatar in composing the manuscript and the status of the Vatican manuscript in the Syriac Life's manuscript tradition have been the subject of debate. Following Peeters, I agree that these two individuals were indeed the authors of the manuscript and that this manuscript represents the autograph of the Syriac Life of Symeon. ${ }^{20}$ In the following paragraphs, I present four reasons for siding with Peeters, since this debate remains unresolved in scholarship.

First, several skilled paleographers have dated the manuscript to the fifth century, providing evidence that the 473 date pertains not only to the text but to the manuscript itself. Wright and Nöldeke comment that the manuscript is "very old." 21 Peeters even identifies two scribal hands, which he believes belonged to Simeon

20 Peeters, Le tréfonds oriental, 113-121. Lane Fox also argues that Simeon bar-Eupolemos and bar-Hațar are the authors. While Lane Fox and I share the same conclusion, he does not engage with the extensive scholarship on the Vatican manuscript and the other versions of the text, arriving at his conclusion solely based on Doran's translation and Torrey's comments. Robin Lane Fox, "The Life of Daniel," in Portraits: Biographical Representation in the Greek and Latin Literature of the Roman Empire, ed. M. J. Edwards and Simon Swain (Oxford: Clarendon Press, 1997), 181.

21 Wright accepts the 473 date. Wright, A Short History of Syriac Literature, $56 \mathrm{n} 3$. Nöldeke advocates for the very early date of the manuscript, although he does not come out and state that the manuscript must be dated to 473. Nöldeke, Sketches from Eastern History, 225 n1-2. 
bar-Eupolemos and bar-Hațar themselves. ${ }^{22}$ Hatch accepts the 473 date, positing the Vatican manuscript as the fifth earliest dated Syriac manuscript in his Album of Dated Syriac Manuscripts. ${ }^{23}$ Based on my inspection of color photos of the manuscript, I agree with Wright, Nöldeke, Peeters, and Hatch's paleographical assessment of the manuscript. ${ }^{24}$ The manuscript's scribes write in a very early estrangelà script. They employ syamè points. They occasionally place a single point over feminine possessive pronouns and masculine and feminine demonstrative pronouns, both regular scribal practices by the fifth century. ${ }^{25}$ On the whole, the fifth-century scribes leave out points above and beneath verbs to differentiate the orthographically similar forms of the peal active participle and the peal perfect active indicative. Such points are regularly omitted in fifth-century manuscripts, demonstrating the great age of this

22 Peeters, Le tréfonds oriental, 113. Peeters does not state where he sees the hand of the scribe change. Ff. $1 \mathrm{a}$ and $8 \mathrm{a}-9 \mathrm{~b}$ do preserve a different hand than the rest of the manuscript, but, given that the hand changes on only three folios, it is probable that these folios are simply replacements for damaged folios and do not represent the work of the second scribe. This is supported by the fact that the hand of these folios is later than the fifth century; the dots on lines 8a.2.13 and 8a.2.14 are not characteristic of fifth- or sixth-century Syriac hands. To support the position that this manuscript is the autograph, it could be the case that the two scribes' hands are so similar that they are impossible to tell apart. Also, one scribe could have been responsible for dictating the text, the other for recording it. For other examples of Syriac manuscripts copied by two scribes prior to the tenth century, see Jack Boulos Victor Tannous, "Syria between Byzantium and Islam: Making Incommensurables Speak" (PhD diss., Princeton University, 2010), 112-120.

${ }^{23}$ Hatch, Album, 56, pl. 5.

24 The Biblioteca Apostolica Vaticana has published color photos of this manuscript on their website. See http://digi.vatlib.it/view/ MSS_Vat.sir.160/0006/scroll?sid=e62efcdd42e 7891eeec139cc54fb92e4.

Last accessed June 1, 2015.

25 See, for example, Vatican Syriac Manuscript 160, f. 14a.2.1-27. Examples can also be found on 68a.1-2. This folio is pictured in Hatch, Album, pl. V. For discussion of fifth-century dotting practices, see Hatch, Album, 40 and Judah Benzion Segal, The Diacritical Point and the Accents in Syriac, London Oriental Series (London and New York: Oxford University Press, 1953), 7-23 and 58-77. 
manuscript. ${ }^{26}$ This paleographical evidence refutes scholars who claim that the Vatican manuscript represents a later copy of the 473 text and that the scribe of the manuscript reproduced the 473 colophon..$^{27}$

Second, given that we can securely date the manuscript to the fifth century, it is unlikely that this manuscript represents a copy from an earlier manuscript. Only fourteen years separate the completion of the manuscript from the death of the saint. The argument that Simeon bar-Eupolemos and bar-Hatar worked with an earlier manuscript assumes that one or multiple manuscripts circulated between 459 and 473 . However, recent research disputes concepts of mass production and distribution of literature in the ancient world, focusing instead on specially trained individuals who could make use of literary material, whether for private reading, public recital, commentary, or to make copies. ${ }^{28}$ Late ancient manuscripts circulated by the agency of social networks held together by common purpose and affection. Copies of texts were gifted, loaned, and produced on an individual and as-needed basis. Thus, they functioned within the heterogeneous economy of giftgiving. ${ }^{29}$ In addition, as economic commodities, manuscripts required a substantial investment to produce. Parchment was costly

${ }^{26}$ Segal, The Diacritical Point, 7-23 and 58-77. Note that such points are included on $\mathrm{f}$. $8 \mathrm{a}$, but as argued in note 22 , this hand does not date to the fifth century.

27 Torrey argues that Simeon bar-Eupolemos and bar-Hațar were "authors," but also contends that the Vatican manuscript is a later copy and that the scribe of the manuscript reproduced the colophon. Torrey, however, does not address the paleographical evidence, only working with Assemani's transcription of the Vatican manuscript. This substantially weakens his argument, since the manuscript clearly dates to the fifth century. Torrey, "The Letters," 274-275 for specific commentary on the colophon. Doran cites Torrey's assessment but does not himself comment on the date of the manuscript. Doran, Lives, 197 n292.

28 Haines-Eitzen makes a strong case against the controlled environment of the "scriptorium" in the second and third centuries. Kim Haines-Eitzen, Guardians of Letters: Literacy, Power, and the Transmitters of Early Christian Literature (Oxford and New York: Oxford University Press, 2000), 77-104.

29 Haines-Eitzen, Guardians of Letters, 78-79; Megan Hale Williams, The Monk and the Book: Jerome and the Making of Christian Scholarship (Chicago: University of Chicago Press, 2006), 234-235. 
and the patron would have had to pay for at least one scribe. ${ }^{30}$ Consequently, while we cannot know for sure whether an earlier manuscript preceded the Vatican manuscript, the pragmatics of late antique manuscript production advise that very few manuscripts of the Syriac Life of Symeon circulated immediately after the saint's death and the Vatican manuscript might very well be the first.

Third, the earliest dateable literary witness of the Syriac Life dates to the sixth century. Severus of Antioch made use of the Syriac Life for his homily on Symeon delivered in 513 CE, forty years after the production of the Vatican manuscript. ${ }^{31}$ Jacob of Serugh may have been familiar with the Syriac Life in his homily on Symeon, but this homily offers insubstantial criteria for dating. ${ }^{32}$ Jacob's literary career spanned a fifty year period (approximately 470-521 CE). Scholars have been able to assign dates to very few of Jacob's homilies and study of Jacob's literary corpus is still in its infancy. That said, in 502/3 CE, Jacob held the position of periodeutes in Hawra and in 519 CE was named bishop of Bațan. Many of his homilies were probably written and performed during this period, when he visited various towns, monasteries, and churches as part of his clerical duties. Consequently, it is more likely to assume, at least preliminarily, that this homily dates to the latter half of Jacob's career. Thus, the fact that, to my knowledge, the Syriac Life of Symeon is not attested in literary sources until the sixth century further suggests that in the fifth-century the text experienced a somewhat limited circulation.

Fourth and finally, several scholars have argued that the scribes of both the Vatican manuscript and the sixth-century manuscript

30 On the economics of book production in Egypt, see Roger S. Bagnall, Early Christian Books in Egypt (Princeton, N.J.: Princeton University Press, 2009), 50-69. For a preliminary assessment of the cost of late antique Syriac manuscripts, see Marlia Mundell Mango, "Patrons and Scribes Indicated in Syriac Manuscripts, 411 to 800 AD" (XVI. Internationaler Byzantinistenkongress. Akten II/4 = JÖBG 32:4 [1983]), 3-12.

31 For Severus' homily see M. Brière and F. Graffin, eds. and trans., Homélie Xxx, PO 36 (1974), 608-639. For Brière's dating of the homily, see page 25 of Introduction Générale aux Homélies de Sévère d'Antioche, PO 29 (1960), 7-72.

32 Bedjan, Acta Martyrum et Sanctorum, vol. 4, 650-665. For an English translation, see Susan Ashbrook Harvey, "Jacob of Serug Homily on Simeon Stylite," in Ascetic Behavior in Greco-Roman Antiquity: A Sourcebook, ed. Vincent L. Wimbush (Minneapolis: Fortress Press, 1990), 15-25. 
British Library Add. 14484, ff. 48-133, copied their text from an even earlier manuscript of the Syriac Life of Symeon than that of the Vatican manuscript, based on the many differences between these two manuscripts and the tenth century Georgian translation. ${ }^{33}$ Indeed, there is great diversity throughout the manuscript tradition, but this does not need to indicate that there was an earlier manuscript from which all versions sprung. Rather, it suggests that the genre of hagiography allowed for scribal revision, addition, and omission, phenomena documented in many hagiographies. ${ }^{34}$ Peeters counters detractors of the Vatican manuscript by suggesting that it is more likely that a scribe try to complete a disorganized work, such as that of the Vatican manuscript, than rewrite a manuscript in a completely disorganized fashion. ${ }^{35}$ Consequently, the diversity of order, word choice, and at times content of the manuscripts does not necessarily undermine the position that the Vatican manuscript is the autograph of the text.

In summary, the paleographic evidence corroborates the 473 date of the manuscript. The pragmatics of manuscript production and earliest literary attestations both strengthen the conclusion that

33 Doran, Lives, 49; Arthur Vööbus, History of Asceticism in the Syrian Orient; a Contribution to the History of Culture in the Near East, vol. 2, CSCO 197 (Louvain: Secrétariat du CSCO, 1960), 209-210. For a transcription of British Library Add. 14484, ff. 48-133, see Bedjan, Acta Martyrum et Sanctorum, vol. 4, 507-644. For the Georgian translation of the Life, see Gérard Garitte, ed., Vies Géorgiennes de S. Syméon Stylite l'ancien et de S. Ephrem (Louvain: L. Durbecq, 1957). Torrey, Lietzmann, and Lent state a preference for the text of the sixth-century Add. 14484, ff. 48-133, based on their assessment of the polished and orderly character of the text. Torrey, "Letters," 74-76; Lietzmann, Das Leben des Heiligen Symeon Stylites, 211-214; Lent, "The Life of St. Simeon Stylites," 104-111. Doran refutes Lent, Lietzmann, and Torrey's premises for assessing the manuscript, pointing out that there were multiple ways to organize a life in Late Antiquity. Chronology need not be the determining factor. Robert Doran, "Compositional Comments on the Syriac Versions of the Life of Simeon Stylites" (AB 102 [1984]), 35-48.

${ }^{34}$ For example, see the various versions of the Life of the Man of God. Doran has translated three different versions of this text in Stewards of the Poor: The Man of God, Rabbula, and Hiba in Fifth-Century Edessa, Cistercian Studies Series 208 (Kalamazoo. Mich.: Cistercian Publications, 2006), 338.

${ }^{35}$ Peeters, Le tréfonds oriental, 117. 
very few, if any, other manuscripts circulated in the 460s and 470s. They also warn against assuming that the Vatican manuscript was a second copy transcribed almost immediately after some earlier copy. Thus, while it is impossible to rule out the existence of an earlier manuscript from which Simeon bar-Eupolemos and barHatar transcribed their text, there are strong grounds to suggest not only that Simeon bar-Eupolemos and bar-Hațar were the authors of the text, but also that the Vatican manuscript represents the autograph of the text. Of course, it is probable that Simeon barEupolemos and bar-Hațar compiled a set of earlier materials which existed in draft form prior to the composition of the Vatican manuscript, but in the Vatican manuscript we have the two authors' final product meant for publication, that is, making it available to be copied by other scribes. ${ }^{36}$

Unfortunately, Simeon bar-Eupolemos and bar-Hațar provide no other information about themselves. We do not know where they were from, where and how they were trained, where they composed the text, or, most importantly, how they were involved with cultic devotion to Symeon. As discussed above, scholars have generally assumed that the text of the Syriac Life of Symeon is affiliated either with Symeon's personal disciples, a monastic community in Telneshe, or a monastic community upon Qal'at Sem'an. Scholars rarely defend or expand upon this assumption; instead, they work from this assumption in analyzing the text. Given the importance of the Syriac Life of Symeon and the Vatican manuscript in specific for the development of cultic devotion to Symeon, Syriac manuscript studies, and the history of Syriac literature, the context of production of the manuscript deserves precise assessment.

On this point, scholars have overlooked a central detail in the colophon. Simeon bar-Eupolemos and bar-Hațar explicitly praise a second set of individuals, the priest Simeon (not to be confused with the author Simeon bar-Eupolemos or the saint himself) and the archdeacon Cyrus, stating that they completed their work, "in the time of the excellent and eminent doer of God's good deeds, the priest Mar Simeon, and in the time of his archdeacon Mar

36 On the Syriac Life's earlier sources, see Doran's discussion of miracle clusters in "Compositional Comments," 35-48; Torrey's discussion of letters in "Letters," 254-257; and Festugière, Antioche païenne et chrétienne, 354-356. 
Cyrus." In praising the priest and archdeacon, the scribes place themselves in relationship with an ecclesiastical institution, rather than a monastery as previous scholars have suggested. While priests and deacons were of course affiliated with monasteries in the fifth century, the colophon never mentions a monastery nor do Simeon bar-Eupolemos and bar-Hațar identify themselves as monks. Thus, the evidence from the colophon best supports that Simeon barEupolemos and bar-Hatar worked in a church.

A number of fifth- and sixth-century Syriac manuscripts were produced in churches and paid for by priests. ${ }^{37}$ The very early British Library Add. 14425, which dates to $464 \mathrm{CE}$, was both copied and paid for by a priest in a church in Amida. ${ }^{38}$ The sixthcentury British Library Add. 14591 was written at the expense of

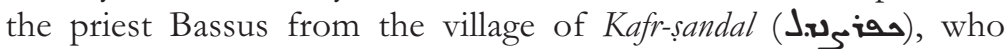
then gifted the manuscript to the Tell 'Ada monastery. ${ }^{39}$ In 611 CE, the priest Elias of Hulban, the deacon Cyrus, Simeon, and Severus paid for British Library Add. 12135 and Severus transcribed it, producing it for a congregation of solitaries at a place called Kawkbà

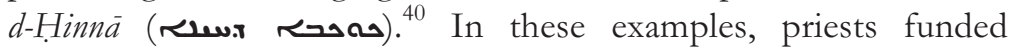
manuscript production, probably with money at least partially procured from their congregation. While in two of the examples above the priests gifted the manuscripts to ascetic communities, they also certainly must have overseen the copying of scriptures, services books, homilies, and other genres of literature for use in their own churches. Although these examples are far more explicit

37 On this point, see Mango, "Patrons and Scribes," 3-12 and "Production of Syriac Manuscripts, 400-700," in Scritture, Libri e testi nelle aree provinciali di Bisanzio: atti del seminario di erice (18-25 Settembre 1988), ed. Guglielmo Cavallo et al. (Spoleta: Centro italiano di studi sull'alto Medioevo, 1991), 165-166.

38 William Wright, Catalogue of Syriac Manuscripts in the British Museum Acquired since the Year 1838, vol. 1-3 (London: Gilbert and Rivington Printers, 1870). For this specific manuscript, see vol. 1, 3-5.

39 Wright, Catalogue of Manuscripts, vol. 2, 669-673. Enno Littmann comments on the possible location of Kafr-sandal on p. 186 of "Zur Topographie der Antiochene und Apamene" (Zeitschrift fur Semitistik 1 [1922]), 163-195.

40 Ibid., vol. 2, 486-487. The toponym translates, "Star of Hinnā." See Littmann, "Zur Topographie der Antiochene," 185 for the possible location of Kawkbā d-Hinnā. 
than the Vatican manuscript's colophon, the mention of the priest and archdeacon suggests that Simeon bar-Eupolemos and barHatar were financially supported by the two ecclesiastical leaders, who distributed funds to pay for the parchment and the scribes' labor. Perhaps the church had even collected sources about the Stylite, such as letters or short miracle accounts, to which Simeon bar-Eupolemos and bar-Hațar were provided access and compiled. ${ }^{41}$

Given that Simeon bar-Eupolemos and bar-Hațar do not explicitly state that the priest Simeon and the archdeacon Cyrus paid for the manuscript, one must be cautious in asserting the priest and archdeacon's influence over the text. Nevertheless, as Harvey observes, the text of the Vatican manuscript does emphasize the integration of the saint Symeon's ascetic practice into the liturgical life of the church. Priests, deacons, and other ecclesiastical clerics monitored Symeon's prayer life and fasting. They led suppliants in ritual processions for intercession with the saint, mediating the saint's leadership in relation with the larger worshiping community. The liturgical calendar framed Symeon's ascetic practices and dictated the schedule of the cult site; Symeon's enclosure was barred during Lent and special feasts were celebrated with Eucharistic liturgy. ${ }^{42}$ Simeon bar-Eupolemos and bar-Hațar's emphasis on ecclesiastical ritual reflects their close relationship with their local ecclesiastical community and the potential support from said community.

\section{THE EPIGRAPHIC EVIDENCE}

While the colophon establishes the institutional context of composition, at first glance it does little to help with the location of composition. As stated at the outset of the article, scholars have failed to notice epigraphic evidence which firmly places the production of the manuscript in Telneshe and further clarifies the institutional and economic context of Simeon bar-Eupolemos and bar-Hațar's literary activities. This section argues that, at the same time as they oversaw and financed the production of the Vatican manuscript, the priest Simeon and the archdeacon Cyrus were responsible for building the first major hostel (pandocheion) in

${ }^{41}$ For sources of the Syriac Life of Symeon, see note 36.

${ }^{42}$ Harvey, "The Stylite's Liturgy," 523-525. 
Telneshe. The production of the Vatican manuscript was part of a larger project to promote pilgrimage to Symeon the Stylite's cult site.

In northern Syria, the Limestone Massif is known for its fertile plains framed by broad stretches of low-lying limestone hills (also called by their Arabic name, jebels) and over 700 villages which dotted the ancient landscape. The well-preserved archaeological remains provide a wealth of information regarding these villages' economic, social, and religious life. ${ }^{43}$ Telneshe, or modern Deir Sem'an, is located on the northernmost jebel of the Limestone Massif, between modern Antakya and Aleppo [fig. 1]. The cult site where Symeon's column still stands, now called Qal'at Sem'an, crowns the hill immediately adjacent to Telneshe [fig. 2]. Although a prominent town in the sixth century, from the first century until the time that Simeon bar-Eupolemos and bar-Hatar composed their version of the Syriac Life, Telneshe was still a fairly small village, overshadowed by larger villages on the plain such as Refade and Taqle. $^{44}$ Nevertheless, the archaeological and epigraphic evidence preserved in Telneshe and the Limestone Massif offers a rich social and economic context in which to examine cultic devotion to Symeon the Stylite and late antique Syriac manuscript production. $^{45}$

43 Jebel or jabal simply means 'hill' or 'mountain' in Arabic. The two prominent archaeological surveys of the region remain Georges Tchalenko, Villages antiques de la Syrie du nord; le massif $d u$ bélus à l'époque romaine, vol. 1-3, Institut français d'archéologie de Beyrouth (Paris: P. Geuthner, 1953) and Georges Tate, Les campagnes de la Syrie du nord du iie an viie siècle: un exemple d'expansion démographique et économique dans les campagnes à la fin de l'antiquité, Bibliothèque archéologique et historique 133 (Paris: Libr. orientaliste P. Geuthner, 1992). In addition, archaeologists have carried out excavations at specific sites throughout the region.

${ }^{44}$ Tchalenko, Villages antiques, vol. 1, 205-206.

$45 \mathrm{Qal}^{6}$ at Sem'an has been the subject of extensive archaeological inquiry. For a recent overview of archaeological research at the site and further bibliography, see Jean-Pierre Sodini and Jean-Luc Biscop, "Qal'at Sem'an and Deir Sem'an: naissance et développement d'un lieu de pèlerinage durant l'antiquité tardive," in Arcbitecture Paléochrétienne, ed. J. M. Spieser (Gollion: Infolio, 2011), 11-59. While scholars have produced a rich bibliography of archaeological publications for the Limestone Massif, few have studied Syriac literary culture and the production of Syriac manuscripts in the region. For an introductory discussion of this topic, see 
Between the years 471 and 479, Telneshe saw the construction

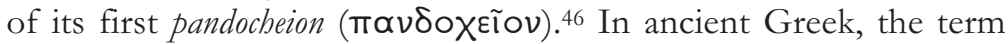
pandocheion literally means 'accepting all comers;' in the ancient world, a pandocheion was a place where travelers were offered lodging in exchange for money. ${ }^{47}$ It contrasted with a xenodocheion

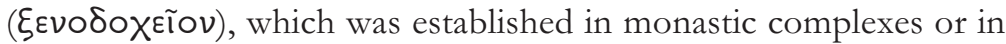
association with churches and catered specifically to pilgrims, the sick, and the poor. ${ }^{48}$ Nevertheless, given the proximity of the pandocheion in Telneshe to Symeon's cult site, certainly it catered to pilgrims. Labeled a pandocheion rather than a xenodocheion, it may have appeared less exclusive to non-Christian travelers. Indeed, Theodoret and the Syriac Life of Symeon report that Symeon attracted a substantial pagan and Arab clientele.

This pandocheion was an important early addition to infrastructure for pilgrims visiting Telneshe and Qal'at Sem'an. The pandocheion [labeled 'Andron' on fig. 2] was located along the northsouth road next to the intersection of the sacred way which led up the hill to Qal'at Sem'an. It occupied a prime location for pilgrims preparing or completing their visit to the column. The first phase of construction of the pandocheion [A, B, and $\mathrm{C}$ on fig. 3], taking place between 471 and $479 \mathrm{CE}$, was contemporary with the first years of construction of the monumental pilgrimage complex at Qal'at Sem'an, which began between 470 and 474 . However, the funding, commissioning, and construction of the pandocheion were

Mango, "Patrons and Scribes," 3-12 and "Production of Syriac Manuscripts," 165-166.

46 The complex's identification as a hostel is based not only on the

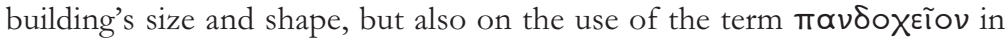
two separate inscriptions. See Louis Jalabert and René Mouterde, Inscriptions grecques et latines de la Syrie, vol. 2 (Paris: P. Geuthner, 1929), no. 416-417, p. 233-234; William Kelly Prentice, Greek and Latin Inscriptions, Publications of an American Archæological Expedition to Syria, 18991900 (New York: The Century co., 1908), no. 121-122, p. 135-136. Jalabert and Mouterde's publication is abbreviated below as IGLS.

47 Olivia Remie Constable, Housing the Stranger in the Mediterranean World: Lodging, Trade, and Travel in Antiquity and the Middle Ages (Cambridge: Cambridge University Press, 2003), 4-7.

${ }_{48}$ Constable, Housing the Stranger, 17; Vööbus, History of Asceticism, vol. 2, 363-365. Although he provides several useful examples of xenodocheia, Vööbus confuses the Telneshe pandocheion with a xenodocheion. 
independent of the construction at Qal'at Sem'an. ${ }^{49}$ Construction of the pandocheion must have required a substantial investment of resources for the individual or individuals who paid for its construction. The pandocheion was quite large, comprised of three wings and boasting several long, rectangular, multi-story buildings, with facilities for lodging, dining, and stabling. ${ }^{50}$

A series of inscriptions located on the lintels of the doors of this pandocheion make it possible both to date the building precisely to 471-479 CE and to associate a certain Simeon and possibly a certain Cyrus with its construction, the two individuals who, I argue, are the same priest Simeon and archdeacon Cyrus named in the colophon of the Vatican manuscript. In the following paragraphs, I present the relevant details in these inscriptions with precision, in order to allay any doubts about their interpretation and significance.

The first inscription, located on a lintel decorated with three rosettes, gives the earliest documented date for the complex,

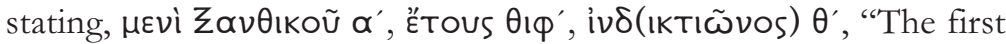
day of the month of Xanthikos, the year 519, the ninth indiction." The year 519 in the Antiochene calendar corresponds to the year $471 \mathrm{CE}^{51}$ A second inscription, still in situ on a lintel of one of the pandocheion's doors, gives the builder's name, the function of the complex, and a later date of $479 \mathrm{CE}$.

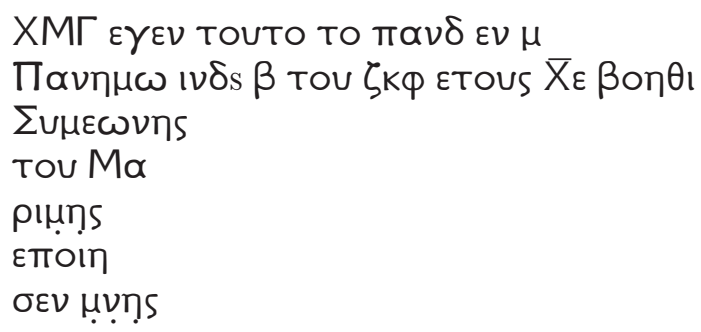

49 The patron of the monumental pilgrimage complex is unknown, although Tchalenko and Lane Fox argue that either the Emperor Leo or the Emperor Zeno ought to be identified as the patron. On the patronage and date of the pilgrimage complex, see Tchalenko, Villages antiques, vol. 1, 227-231, and Lane Fox, "The Life of Daniel," 193-195.

50 This phase of development in Deir Sem'an is discussed in Tchalenko, Villages antiques, vol. 1, 208-209.

51 Tchalenko, Villages antiques, vol. 2, no. 16, pl. CXLIV and vol. 3, no. 16 , p. 19. 


$$
\theta+\eta^{52}
$$

Prentice interprets and translates this inscription, $Х М Г$.

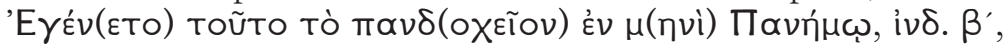

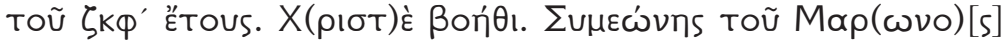

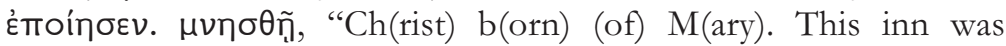
(built) in (the) month Panemos, indiction 2, of the $527^{\text {th }}$ year. O Christ, help (us)! Symeonēs (son) of Marōn built it: may he be remembered!" 53 The year 527 in the Antiochene calendar corresponds to the year 479 CE. Based on Jalabert and Mouterde's transcription provided above, a more recent transcription than the

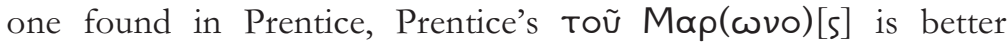
transcribed as Mapıuns. A third inscription, also located on the lintel of one of the pandocheion's doors, again names Symeonēs. ${ }^{54}$

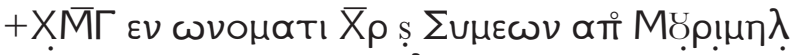

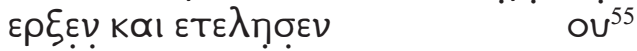

Prentice interprets and translates this inscription, $+X M \Gamma$. 'Ev

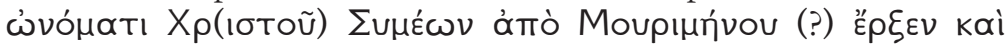

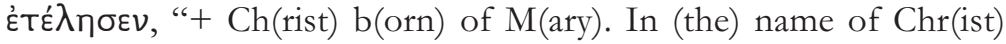
Symeon from (the village of) Mūrimîn (?) wrought and finished..."56

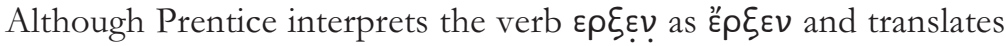
it as 'wrought,' it is better interpreted $\tilde{\rho} \rho \varepsilon \mathcal{V}$ and translated 'began. ${ }^{57}$ Based on the use of $\propto \pi \pi^{\circ}$ MỤp! $\mu \eta \lambda$ in this third inscription

52 IGLS vol. 2, no. 416, p. 233.

53 Prentice, Greek and Latin Inscriptions, AAES, no. 121, p. 135.

54 Tchalenko associates this inscription with the pandocheion. Tchalenko, Villages antiques vol. 1, p. 209. Previous commentators state simply that it was carved upon the lintel of a building located on the south side of the same street as the pandocheion, approximately fifty feet away from the complex. IGLS vol. 2, no. 418, p. 234; William Kelly Prentice, Greek and Latin Inscriptions, Publications of the Princeton University Archaeological Expedition to Syria in 1904, 1905 \& 1909, III B (Leiden: Brill, 1922), no. 1156, p. 173-174.

55 IGLS vol. 2, no. 418, p. 234.

56 Prentice, Greek and Latin Inscriptions, PAES III B, no. 1156, p. 173174.

57 The verb, $\varepsilon \rho \xi \varepsilon v$, is difficult to translate in the context of north Syrian inscriptions. Prentice makes no comment upon the verb or from what root he derived its meaning. I see two probable possibilities for how to interpret $\varepsilon \rho \xi \varepsilon \nu$, as well as two less probable possibilities. If we lengthen 
in combination with the term Mapıuns in the second inscription, Jalabert and Mouterde suggest that both terms are alternate spellings of the Aramaic toponym Marimîn. Jalabert and Mouterde make no recommendations as to where Marimîn is located. 58 Perhaps the toponym is related to the Greek Mapió $\mu \mu \eta$, 'Mariamme.' Several towns in Syria bear this toponym; the most well-known of these is located south of Rafaniya between Homs and the Mediterranean. ${ }^{59}$

While the inscriptions identify a certain Symeonēs, or Simeon, of Marimin, the dates when he undertook and completed the construction of the pandocheion, and his place of origin, they do not

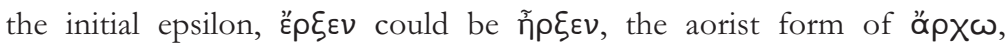
meaning 'he began.' North Syrian inscriptions frequently exchange an epsilon for an eta. I have selected this interpretation because it both fits the context of the inscription and the form does not require substantial change. Alternatively, the verb Ép $\xi \in \nu$ could also be related to $\rho \dot{\varepsilon} \zeta \omega$, meaning 'to do' or 'to accomplish.' However, the aorist of this verb is normally written है $\rho \rho \xi \alpha$. It generally appears in poetry, and is not used often in inscriptions. One contemporary example occurs in a commemorative inscription on a sixth-century baptistery in Apollonia,

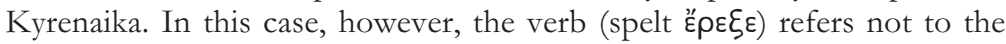
completion of a building but to the washing away of sins which have been

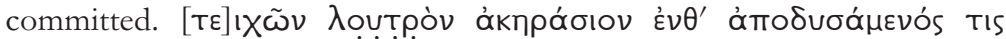

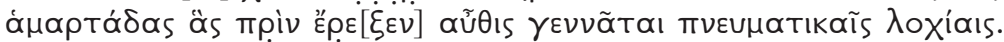

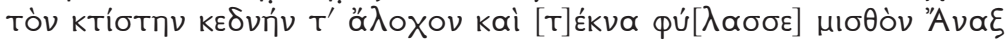

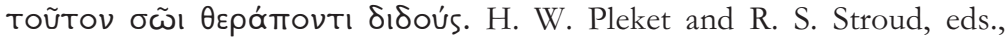
"Apollonia. Construction of a baptistery, 6th cent. A.D. (?)," Supplementum Epigraphicum Graecum, vol. XXVII (Alphen aan den Rijn, the Netherlands: Sijthoff \& Noordhoff, 1980), no. 1140, p. 290-291. While the date, building type, and inscription type offer a compelling comparison, the actual use within the inscription is different from the inscription in question. In addition, two other improbable candidates are हैp $\gamma \omega$, meaning 'to shut in,' 'shut out,' 'enclose,' or 'hinder,' and ép $\delta \omega$, meaning 'to do.' The verb हp $\delta \omega$ often carries a negative connotation, such as 'to do harm' or 'to do mischief.' Consequently, the meanings of both verbs make them poor fits for this inscription.

${ }^{58}$ Jalabert and Mouterde presume it is a toponym based on its use with $\propto$ iा in IGLS vol. 2, no. 416, p. 233; IGLS vol. 2, no. 418, p. 234.

59 "Mariamme," Brill's New Pauly, ed. Hubert Cancik and Helmuth Schneider (Brill Online, 2013). http://referenceworks.brillonline.com/ entries/brill-s-new-pauly/mariamme-e723620. Web page last accessed on October 30, 2013. 
state Simeon's specific role in building the pandocheion. Previous

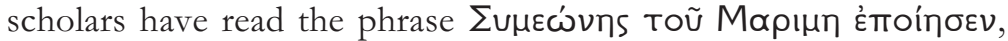
"Simeonēs of Marimîn built (it)," to imply that Simeon was the TEXVítnS, or 'architect,' of the building. ${ }^{60}$ Although the term TEXVítns is not used in this inscription, it appears frequently in north Syrian inscriptions and may describe correctly Symeon's role in the construction of the pandocheion. ${ }^{61}$ In north Syrian inscriptions,

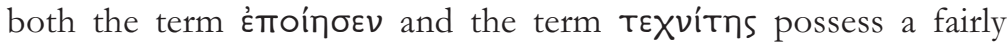
broad semantic range. The verb Émoínбev can imply that the subject of the verb was involved in the physical labor or crafting of an object or building, but can also indicate that he commissioned, designed, or administered the construction of a building. ${ }^{62}$ Similarly, the term TEXVítns can be used of a craftsman, but also is used of an individual with far more influence over a building than a mere manual laborer.

60 Jalabert and Mouterde, Tchalenko, and Azpeitia all identify Simeon as the architect in their discussion of the building. IGLS vol. 2, no. 416, p. 233; Tchalenko, Villages antiques, vol. 1, 208-209; Johanne Azpeitia and Alain Desreumaux, "Deir Sim'ân, monastère nord-ouest: présentation de l'église; avec un appendice épigraphique; les inscriptions syriaques" (TM 15 [2005]), 37-66. Azpeitia authored the archaeological presentation of the monastery; Desreumaux the inscriptions. Azpeitia briefly discusses the 'architect' Simeon on 53-54.

${ }^{61}$ For specific references to TEXVÍtns in building projects in northern Syria, see IGLS vol. 2, no. 595, p. 325; Prentice, Greek and Latin Inscriptions, AAES, no. 35, p. 60-61. This inscription is from Kokanaya and dates to 378 CE. IGLS vol. 2, no. 555, p. 303; Prentice, Greek and Latin Inscriptions, AAES, no. 66, p. 84-85. This inscription is from Babisqa and dates to 389 CE. IGLS vol. 2, no. 509, p. 281; Prentice, Greek and Latin Inscriptions, AAES, no. 73, p. 90. This inscription is from Ksegbe and dates to 414/415 CE. IGLS vol. 2, no. 535, p. 295; Prentice, Greek and Latin Inscriptions, AAES, no. 57, p. 76-77. This inscription is from Dar Qita and dates to 418 CE. IGLS vol. 2, no. 597, p. 326; Prentice, Greek and Latin Inscriptions, AAES, no. 37, p. 62. This inscription is also from Kokanaya and dates to $431 \mathrm{CE}$. These villages are all located in Jebel Barisha, the jebel approximately twenty to thirty kilometers southwest of Telneshe.

62 Similar to Émoínбev, the Latin verb facere also carries a broad meaning in building inscriptions. Mireille Cébeillac-Gervasoni, "Les travaux publics à la fin de la république dans le Latium et la Campanie du Nord: la place de la classe dirigeante et des familles de notables" (Cabiers du Centre Gustave Glotz 2 [1991]), 200. 
In certain cases, the verb Émoínбev and the term TEXVítns indicate that the individual involved was a skilled worker or artisan. ${ }^{63}$ For example, an inscription from Baqirha dating to 357 $\mathrm{CE}$ and carved onto the lintel of the village's west church reads:

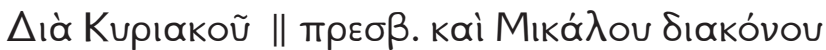

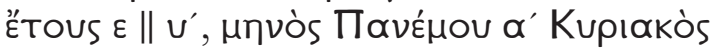

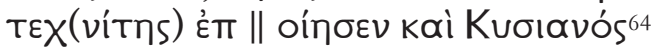

By the priest Kyriakos and the deacon Michael

In the year 405, in the first month of Panemos, Kyriakos

the architect built (it) and also Kysianos. ${ }^{65}$

In this inscription, the role of each individual is clearly defined. Kyriakos and Michael are respectively the church's priest and deacon. The $\Delta$ iơ followed by the genitive construction expresses agency, indicating that these two individuals were responsible for overseeing the construction of the church. Their names appear in the first line of the commemorative inscription, attesting to their primary importance. A second Kyriakos bears the label $\tau \varepsilon X(v i ́ t \eta S)$; given the sentence construction, Kysianos also ought to be identified as a TEXVIítns. Presumably, these two individuals were skilled craftsmen, and did not bear the same leadership role as the

63 This meaning of the term TEXVítns is common throughout the Mediterranean and continued to be used into the middle and late Byzantine period. Robert G. Ousterhout, Master Builders of Byzantium (Princeton, N.J.: Princeton University Press, 1999), 44. Inscriptions from northern Syria also employ other terms for artisans or workmen, such as

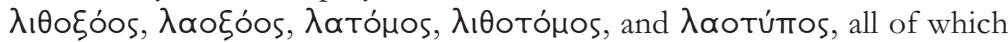
mean 'mason,' or one who dresses and polishes stone. Howard Crosby Butler and E. Baldwin Smith, Early Churches in Syria. Fourth to Seventh Centuries, PMAA (Amsterdam: Adolf M. Hakkert, 1929), 255.

${ }^{64}$ Baqirha is located on Jebel Barisha, approximately twenty to thirty kilometers southwest of Telneshe. This inscription is no. 6 in Jacques Jarry, "Nouvelles inscriptions de Syrie du Nord" (ZPapEpig 47 [1982]), 73103.

65 I follow Jarry's translation. Jarry translates, "Par le prêtre Cyriaque et le diacre Michel, en l'an 405 (de l'ère césarienne d'Antioche $=357$ de notre ère), le premier du mois de Panemos, le maitre d'oeuvre Cyriaque l'a fait, ainsi que Kysianos." Jarry, "Nouvelles inscriptions de Syrie du Nord," no. 6, p. 75 . 
priest Kyriakos and the deacon Michael in the creation and construction of the building.

In north Syrian inscriptions, a TEXvítns might also shoulder far more responsibility than a skilled craftsman or artisan. As Tchalenko and Loosely point out, a building's TEXvítns takes center stage in north Syrian inscriptions far more frequently than the building's patron. ${ }^{66}$ Patrons are named only rarely, the TEXVítns named frequently. ${ }^{67}$ Consequently, in many cases the term 'architect' does not adequately describe the responsibilities of a TEXVítns; a more fitting term might be 'master of works' or 'director of works.' ${ }^{6}$ A TEXVítns could be responsible for designing, administering the funds, and overseeing the construction of a building.

A set of inscriptions from Babisqa illuminates this more expansive meaning of TEXVÍtns, while also providing a clear case in which the verb Émoínoev designates far more than the physical labor of constructing a building. These inscriptions both

${ }^{66}$ George Tchalenko, Eglises syriennes à Bêma, Bibliothèque archéologique et historique and Institut français d'archéologique du procheorient (Paris: Librairie orientaliste P. Geuthner, 1990), 118-119; Emma Loosley, The Architecture and Liturgy of the Bema in Fourth- to Sixth-Century Syrian Churches, Texts and Studies in Eastern Christianity (Leiden: Brill, 2012), 36-37.

67 Bulter compares the terms and their frequency for architects, contractors, and craftsmen in north Syrian inscriptions. Although his survey of inscriptions is incomplete, his chart provides a helpful approximate estimate of the preference for certain terms over others. The

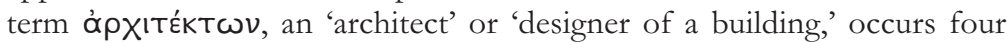

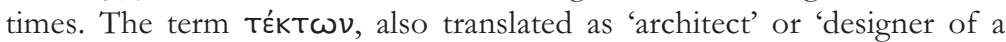
building,' occurs seven times. The term тєXvítns occurs twenty times.

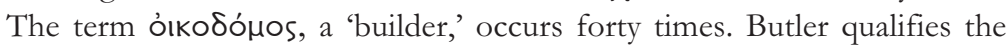
meaning of the term óıкóśnos, adding that there may have been no substantial difference between the function of a designer and a builder; in many cases the architect could also function as a builder, contractor,

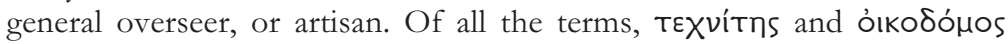
appear the most frequently and are the most expansive in meaning. The term KTíotns, which elsewhere in the late Roman Empire is used as 'founder' or 'patron,' rarely appears in north Syrian inscriptions. Butler, Early Churches in Syria, 254-256.

68 Tchalenko, Eglises syriennes, 118-119; Loosley, Architecture and Liturgy of the Bema, 36-37. 
commemorate the well-studied Markianos Kyris, the priest and master of works for churches in Ksedjbeh and Dar Kita as well as Babisqa. ${ }^{9}$ The first inscription, carved upon the lintel of a church and dating to $401 \mathrm{CE}$, reads:

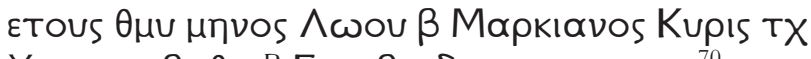

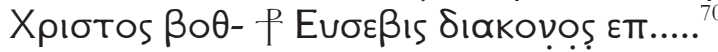

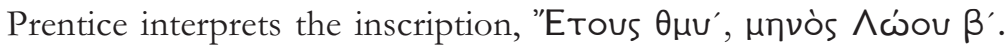

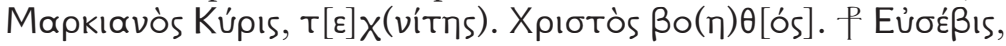

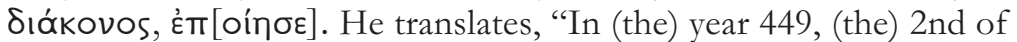
(the) month Loös. Markianos Kyris (was the) architect. Christ (the) helper. P Eusebis, deacon, made (this)." 71 In this inscription, we meet two individuals involved in the construction of the building, the TExvítns Markianos Kyris and the deacon Eusebis. Although labeled a тEXVítns, Markianos Kyris is commemorated before Eusebis, indicating his primary responsibility for the church's creation. However, Eusebis also played some role in overseeing the

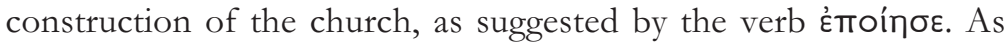
in the Baqirha inscription, the honor of constructing a church was shared between a TEXvítns and a deacon.

In a second inscription associated with the same church, Markianos Kyris is again mentioned, but this time identified as a

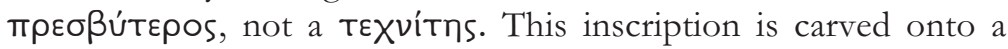
lintel of the baptistery and dates to $390 \mathrm{CE}$.

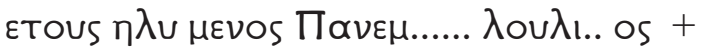

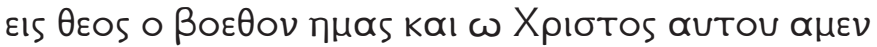

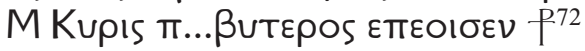

With the exception of the fragment $\lambda_{\text {ouv }} \lambda_{\text {I.. os, }}$ the inscription is

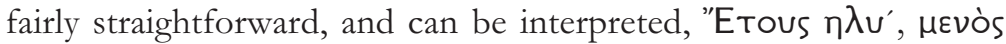

${ }^{69}$ For an analysis of the building projects of this individual, see David Milson, "The Syrian Technites Markianos Kyris († 425 C.E.)" (ZDPV 119: 2 [2003]), 159-182.

${ }^{70}$ IGLS vol. 2, no. 559, p. 305. Babisqa is located on Jebel Barisha.

${ }^{71}$ Prentice, Greek and Latin Inscriptions, AAES, no. 67, p. 86. The year 449 in the Antiochene calendar corresponds to the year $401 \mathrm{CE}$. Prentice

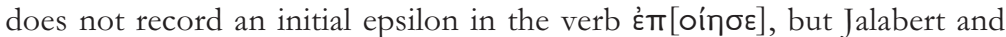
Mouterde's more recent publication confirms the existence of an epsilon as the initial letter of the word.

${ }^{72}$ IGLS vol. 2, no. 561, p. 305. 


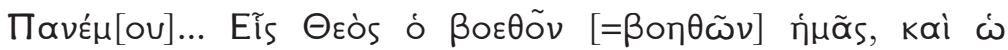

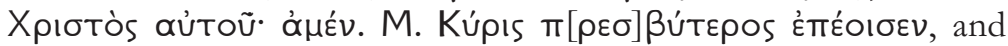
translated, "In (the) year 438, in (the) month Panemos... One God that helps us, and his Christ: amen. M. Kyris, presbyter, made (this)." 73

From these two inscriptions, it is clear that Markianos Kyris

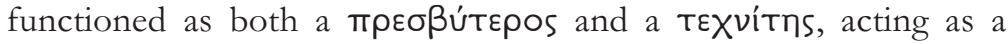
priest and 'director of works' intricately involved in the design, administration of funds, and oversight of the construction of the church. As Tchalenko argues, Markianos Kyris combined knowledge of ecclesiastical issues and the liturgy's architectural demands with building methods specific to the Limestone Massif. ${ }^{74}$ In this case, the verb Éméoı leadership in the building's construction and not the menial labor of a crasftsman.

The Baqirha and Babisqa inscriptions offer compelling comparisons with which to interpret the inscriptions of Telneshe commemorating Simeon of Marimîn. Although the inscription on the pandocheion assigns no title to Simeon of Marimîn, the sole focus on him suggests that he was primarily responsible for overseeing the construction of the pandocheion. The choice of the verb

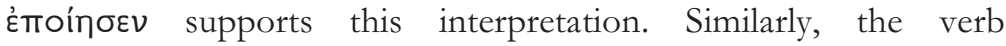

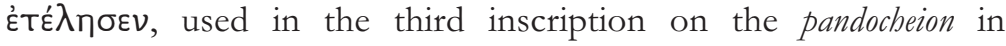
Telneshe, further emphasizes the critical role that Simeon of Marimin played in the building's creation and construction. The

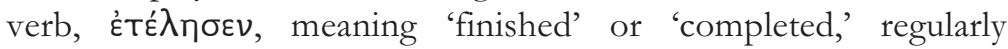
appears in inscriptions from northern Syria. It refers to the activity of the person who commissioned, paid for, designed, or oversaw the construction of the building; it is used of priests, deacons, 'masters of works,' and laypeople. ${ }^{75}$ In addition, the fact that only

73 Here I follow Prentice's transcription and translation. Prentice, Greek and Latin Inscriptions, AAES, no. 67, p. 86. Jalabert and Mouterde

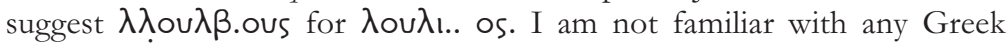
word closely related to $\lambda \lambda$ ou $\lambda \beta$.ous. IGLS vol. 2, no. 561, p. 305-306.

${ }^{74}$ Tchalenko, Eglises syriennes, 118-119.

${ }^{75}$ For an example of $\dot{T} T \varepsilon \dot{\lambda} \lambda \eta \varepsilon \varepsilon v$, see IGLS vol. 4, no. 1409, p. 119; Prentice, Greek and Latin Inscriptions, AAES, no. 241, p. 205-206. This inscription is from Frikya and dates to $325 \mathrm{CE}$. For an undated example from Megeleyya, see IGLS vol. 4, no. 1485, p. 148; Prentice, Greek and

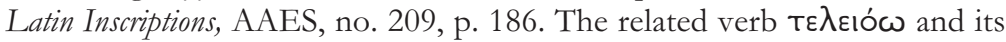


Simeon is mentioned in the inscription further supports this interpretation, placing importance upon Simeon alone.

These inscriptions make a strong case that Simeon of Marimin was the primary individual responsible for the design, administration of funds, and oversight of the construction of the pandocheion complex in Telneshe. Significantly, the timeframe of Simeon of Marimîn's building activities in Telneshe overlaps perfectly with the completion of the Vatican manuscript. Simeon of Marimin directed the construction of the pandocheion between 471 and 479; the priest Simeon and archdeacon Cyrus oversaw the production of the Vatican manuscript in 473 . The similar name and shared timeframe make it a strong possibility that Simeon of Marimîn was the same priest Mar Simeon mentioned in the Vatican manuscript. Although Simeon of Marimîn is not identified as a priest in the pandocheion's inscriptions, Markianos Kyris also does not receive the title 'priest' in the later Babisqa inscription, providing a comparandum for the possibility that this title was also omitted from the inscriptions naming Simeon of Marimîn.

A fourth inscription from Telneshe potentially links Simeon of Marimîn and an individual named Cyrus, further suggesting that these two individuals are the same priest Mar Simeon and the archdeacon Cyrus of the Vatican manuscript. This inscription reads,

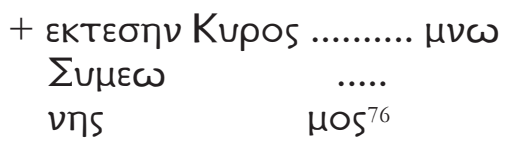

Prentice interpreted the fragmentary inscription, ĚkTıఠєV Kũpos...

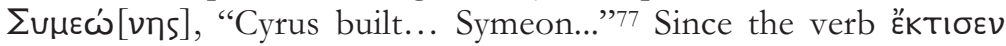

various forms express a similar sentiment. For example, see IGLS vol. 4, no. 1506, p. 157; Prentice, Greek and Latin Inscriptions, AAES, no. 154, p. 155. This inscription is from Hass and dates to the year $378 \mathrm{CE}$. An

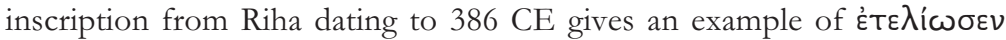
used of both the person responsible for the construction and the craftsman. IGLS vol. 2, no. 689, p. 375-376; Prentice, Greek and Latin Inscriptions, AAES, no. 278, p. 231-232. These towns are all located in Jebel Riha.

${ }^{76}$ IGLS vol. 2, no. 423, p. 236.

77 Prentice, Greek and Latin Inscriptions, AAES, no. 123, p. 137. Waddington, who first documented the inscription, renders the first part of the inscription, "Ekтєoワv kúpos. Philip Le Bas and W. H. Waddington, 
regularly indicates patronage or oversight of a building project in north Syrian inscriptions, the inscription clearly indicates that Cyrus was indeed responsible for the construction of the building upon which the inscription was carved. ${ }^{7}$

The reference to $\Sigma \cup \mu \varepsilon \omega \dot{v n}$ s or $\Sigma v \mu \varepsilon \omega \dot{v}$ is more problematic, as it can either refer to Simeon of Marimîn or the saint Symeon. Unfortunately, the location of the inscription does not clarify the situation. Waddington, who first recorded the inscription in the mid-nineteenth century, remarks that the inscription was carved upon the lintel of a door, but gives no further discussion of the building's function or location. Prentice and Jalabert and Mouterde simply repeat Waddington's description; it is not clear that they saw the inscription during their surveys of Telneshe. ${ }^{79}$ Consequently, it is impossible to know if this inscription should be associated with the pandocheion, in which case $\Sigma v \mu \varepsilon \omega ́ v \eta n$ or $\Sigma v \mu \varepsilon \omega \dot{v}$ would refer to Simeon of Marimîn, or if this inscription should be associated with

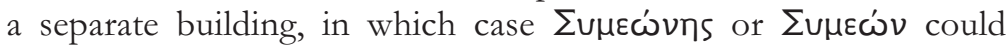
refer either to Simeon of Marimîn or the saint. In his transcription,

Voyage archâeologique en Gráece et en Asie Mineure, vol. 3, pt. 1 (Paris: FirminDidot fráeres, fils et cie, 1870), no. 2693, p. 624. Prentice corrects

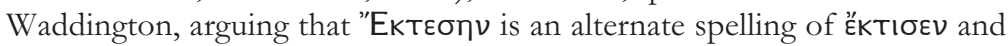
that the word Kupos is best interpreted as a proper name, Kũpos, 'Kyros,' that is, Cyrus.

${ }^{78}$ IGLS vol. 2, no. 443, p. 245; Prentice, Greek and Latin Inscriptions, AAES, no. 116, p. 133. This inscription, from Qatura, dates to 336/337 CE. IGLS vol. 2, no. 460, p. 253-254. This inscription, from Zerzita, dates to the year 375/376 CE. IGLS vol. 2, no. 537, p. 295-296; Prentice, Greek and Latin Inscriptions, AAES, no. 58, p. 77-78. This inscription, from Dar Qita, appears on a baptistery and dates to the years $415 / 6$ or $515 / 6$ CE. IGLS vol. 2, no. 458, p. 252-253. This inscription, from Zerzita, dates to the year 500 CE. These towns are located in Jebel Sem'an, Jebel Halakah, and Jebel Barisha.

79 Le Bas and Waddington, Voyage archâeologique, vol. 3, pt. 1, no. 2693, p. 624. Jalabert and Mouterde as well as Prentice both record Waddington's statement, "Sur un autre linteau, devant la porte il y a plusieurs auges." Prentice comments on Waddington's interpretation while Jalabert and Mouterde offer no other commentary on the inscription. IGLS vol. 2, no. 423, p. 236; Prentice, Greek and Latin Inscriptions, AAES, no. 123, p. 137. Presumably, both Prentice and Jalabert and Mouterde worked from Le Bas and Waddington's publication and were unable to locate this inscription in their surveys of Telneshe. 
Waddington asserts that the second half of the inscription be read

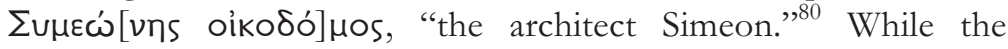

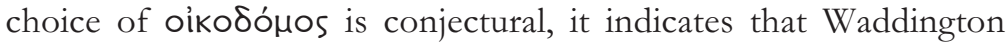
associated this inscription with those on the pandocheion and believed that this inscription referred to Simeon of Marimîn. The possible association of Cyrus with Simeon of Marimin again suggests that these two individuals are the same archdeacon Mar Cyrus and priest Mar Simeon named in the Vatican manuscript. This further indicates that the Vatican manuscript was composed in Telneshe and associates it with two local ecclesiastical leaders actively engaged in developing infrastructure for pilgrims' travel and visit to the cult site.

While inscriptions of northern Syria most frequently attest priests and deacons overseeing the construction of churches or xenodocheia rather than pandocheia, ecclesiastical support of pandocheia is not without precedent in the late antique world. An inscription from Constantina in Osthoene records that the bishop Samuel founded a pandocheion in 513/4. ${ }^{81}$ Like xenodocheia, pandocheia catering to pilgrims played an important role in framing the pilgrimage journey. The Life of Theodore of Sykeon describes a pandocheion near a shrine dedicated to the martyr St. George. The female innkeepers, originally courtesans, rejected their profession for a more holy path. The hostel's cook Stephen donated his excess income to churches and fasted throughout Lent. Theodore grew up in this hostel; he and his mother witnessed visions of St. George there. ${ }^{82}$

${ }^{80}$ Le Bas and Waddington, Voyage archâeologique, vol. 3, pt. 1, no. 2693, p. 624.

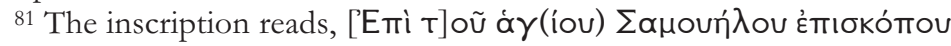

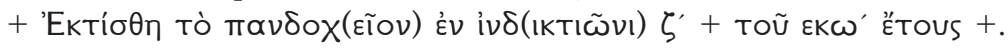
Victor Chabot, "Antiquités de la Syrie du Nord," (BCH 26 [1902]) 200201; Carl Maria Kaufmann, Handbuch der altchristlichen Epigraphik (Freiburg im Breisgau; St. Louis, Mo.: Herder, 1917), 416; Henri Leclercq, "Hôpitaux, hospices, hôtelleries," in Dictionnaire d'archéologie cbrétienne et de liturgie, ed. Fernand Cabrol and Henri Leclercq (Paris: Letouzey et Ané, 1907), 2758.

82 A. J. Festugière, ed. and trans., Vie de Théodore de Sykéôn, vol. 1, Subsidia Hagiographica 48 (Bruxelles: Soc. des Bollandistes, 1970), 3; Elizabeth A. S. Dawes and Norman Hepburn Baynes, trans., Three Byzantine Saints: Contemporary Biographies of St. Daniel the Stylite, St. Theodore of Sykeon, and St. John the Almsgiver (Oxford: B. Blackwell, 1948; reprint 
This example illuminates how a hostel might offer a Christian social environment for pilgrims. In addition, the hosts at pandocheia provided unique interpretations of pilgrimage events and sites, shaping the experience of pilgrims through their stories, explanations, and tours. ${ }^{83}$ Pilgrimage was not simply a means of accessing the special dead or the sites of biblical history. Pilgrims also desired and gained benefit from personal contact with live priests, monks, and holy men. ${ }^{84}$ In these ways, the priest Simeon and archdeacon Cyrus could exert influence over cult practice in Telneshe.

In addition, pilgrims and the investors of pandocheia satisfied a mutual need for legitimacy. Pilgrims had access to infrastructure and support on their often long and multi-staged travel through a region while investors reaped both economic and social rewards..$^{85}$ The construction of pandocheia was part of the broader tradition of benefaction in the late Roman world, both bringing prominence to the funder or overseer of the project while also promoting the public good. Indeed, Simeon states in an above inscription that he built the pandocheion so that he be remembered ( $\mu \nu \eta \sigma \theta \tilde{n})$. A fourth inscription on the pandocheion, still in situ on a lintel on the west side of the complex, wishes well on those pilgrims frequenting the pandocheion and visiting the column, exclaiming, 'Y yía toĩs kupiors

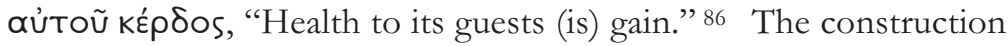

Crestwood, N.Y.: St. Vladimir's Seminary Press, 1996), 88-93. I thank the reviewer for pointing me towards this passage.

${ }^{83}$ Hagith Sivan, "Pilgrimage, Monasticism, and the Emergence of Christian Palestine in the Fourth Century," in The Blessings of Pilgrimage, ed. Robert G. Ousterhout (Urbana: University of Illinois Press, 1990), 54-65.

${ }^{84}$ Ibid., 54-55.

85 Ibid., 62.

86 Tchalenko associates this inscription with the pandocheion. Tchalenko, Villages antiques vol. 1, p. 209. Prentice and Jalabert and Mouterde, writing before Tchalenko's publication, state simply that the lintel was located on the north side of the same street as the pandocheion, but farther up the hill towards the west. Prentice, Greek and Latin Inscriptions, AAES, no. 122, p. 136; IGLS vol. 2, no. 417, p. 233-234. The full inscription reads (IGLS vol. 2, no. 417, p. 233-234):

+ EKTS TOUTO $\pi \alpha \nu \delta s \varepsilon \nu \mu \varepsilon \nu \mu$

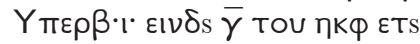

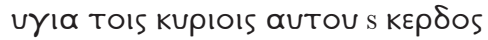


of the pandocheion supported pilgrims in their journey to visit saint Symeon, honored the priest Simeon and possibly the archdeacon Cyrus' patron saint, and offered prominence to the priest and archdeacon and their parish community.

\section{CONCLUSION}

The priest Simeon of Marimin and the archdeacon Cyrus oversaw the production of the Vatican manuscript's version of the Syriac Life of Symeon as well as the construction of a pandocheion in Telneshe. Whereas the pandocheion supported pilgrims who visited Symeon's site in Telneshe, the manuscript honored the saint while also making available for publication the local ecclesiastical community's own version of the saint's life. Through these two complimentary expenditures, we begin to see the priest Simeon and archdeacon Cyrus' very active hands shaping cult life in the decades immediately following Symeon's death.

The implications of this argument are threefold. First, by placing the production of the manuscript in an ecclesiastical context, we are able to analyze the rhetorical project of this version of the Syriac Life with greater precision. Second, by associating the production of the Vatican manuscript with the construction of the pandocheion, we can interpret the manuscript as part of a project promoting Telneshe as the locus of Symeon's sanctity at a critical juncture in the history of Symeon's cult, that is, the period after Symeon's body was removed to Antioch but before or at the very beginning of construction of the monumental pilgrimage complex

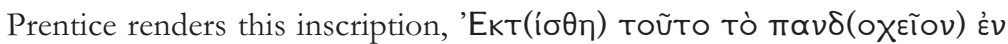

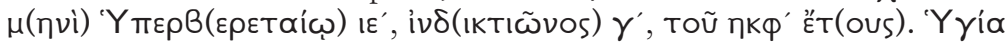
Toĩs Kupíoıs aưToũ Képठos, and translates, "This inn was built in (the) month Hyperberetaios, (on the) $15^{\text {th }}$ (day), indiction 3 , in the $527^{\text {th }}$ year. Health to its masters (is) gain." The year 527 in the Antiochene calendar corresponds to the year $479 \mathrm{CE}$. In his translation of the phrase toĩs kupiois, Prentice refers not to 'masters' in terms of the builder of the pandocheion but rather to the pandocheion's guests. For this reason, I translate Toĩs kupíors as "guests." Prentice, Greek and Latin Inscriptions, AAES, no. 122, p. 136. Jalabert and Mouterde offer a slightly different interpretation

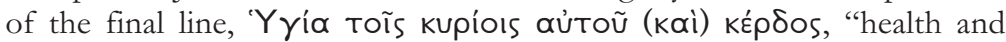
profit to the masters of the hostel," IGLS vol. 2, no. 417, p. 233-234. Prentice also notes the possibility of this translation. Prentice, Greek and Latin Inscriptions, PAES III B, no. 1155, p. 172-173. 
at Qal'at Sem'an. Indeed, the Syriac Life grants attention to the holiness of the enclosure around Symeon's column rather than the relics of his body interred in Antioch. ${ }^{87}$ In addition, the Vatican manuscript, together with the archaeological and epigraphic evidence, illuminates local administration of cult life. Third and finally, the Vatican manuscript, as one of our earliest dated Syriac manuscripts, offers insight into the formation of Syriac as a standardized language. Placing the manuscript concretely in Telneshe provides an opportunity to understand better regional variation in fifth-century Syriac. In addition, it provides a concrete example of production of a Syriac manuscript in western Syria at a very early date in the history of Syriac literature, shedding light on the bilingualism of the Limestone Massif and northern Syria more broadly. In sum, this narrow argument paves the way for exploring further the text of the Vatican manuscript, the history and trajectories of Symeon's cult, and the languages and cultures of late antique Syria.

${ }^{87}$ For discussion of the Syriac Life's emphasis on the cult site rather than Symeon's tomb in Antioch, see Dina Boero, "Promoting a Cult Site without Bodily Relics: Material Substances and Imagined Topography in the Syriac Life of Symeon the Stylite," in Religious Competition in the Greco-Roman World, ed. Nathaniel P. DesRosiers and Lily C. Vuong (Atlanta: Society of Biblical Literature Press, forthcoming). 


\section{FIGURES}

1. 'Ain Delf

2. Qaşr el Banàt

3. Bāb el Hawã

4. Tell 'Aqibrin

5. Tell Ãde

6. Deir Turmanin

7. Qałura

8. Refâde

9. Taqle

10. Bał̧uţa

11. Surqainya

12. Fafertin

13. Burğ Heidar

14. Haräb Š̀ams

15. Kalóta

16. Sinbãr

17. Šeib Sleimãn

18. Šeih Barakait

19. Herbet Šeib Barakât

20. Qal'at Sim'in

21. Deir Sim'ãn

22. Bräd

22. Qassr el Brãd

23. Babisqa

24. Dăr Qíta

25. Bacûde

26. Bamuqqa

27. Qirqbize

28. Bebyo

29. Qalblōxe

30. Dëhes

31. Environs d'el Bãra

32. El Bara: ruines d'el Kafr

33. Muğleya

34. Š̉inšarah

35. Serğilla

36. Dallōza

37. Ruweiba

38. Kfer Rūma

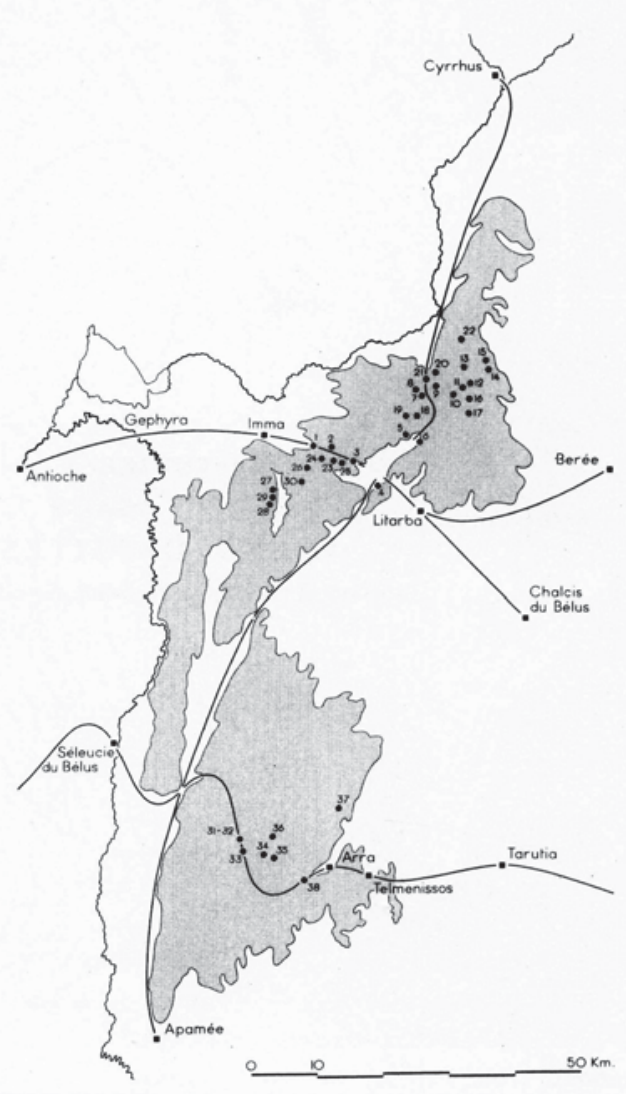

Fig. 1. Map of Limestone Massif. [From Tchalenko, Villages antiques, vol. 2, pl. cxxiv.] 


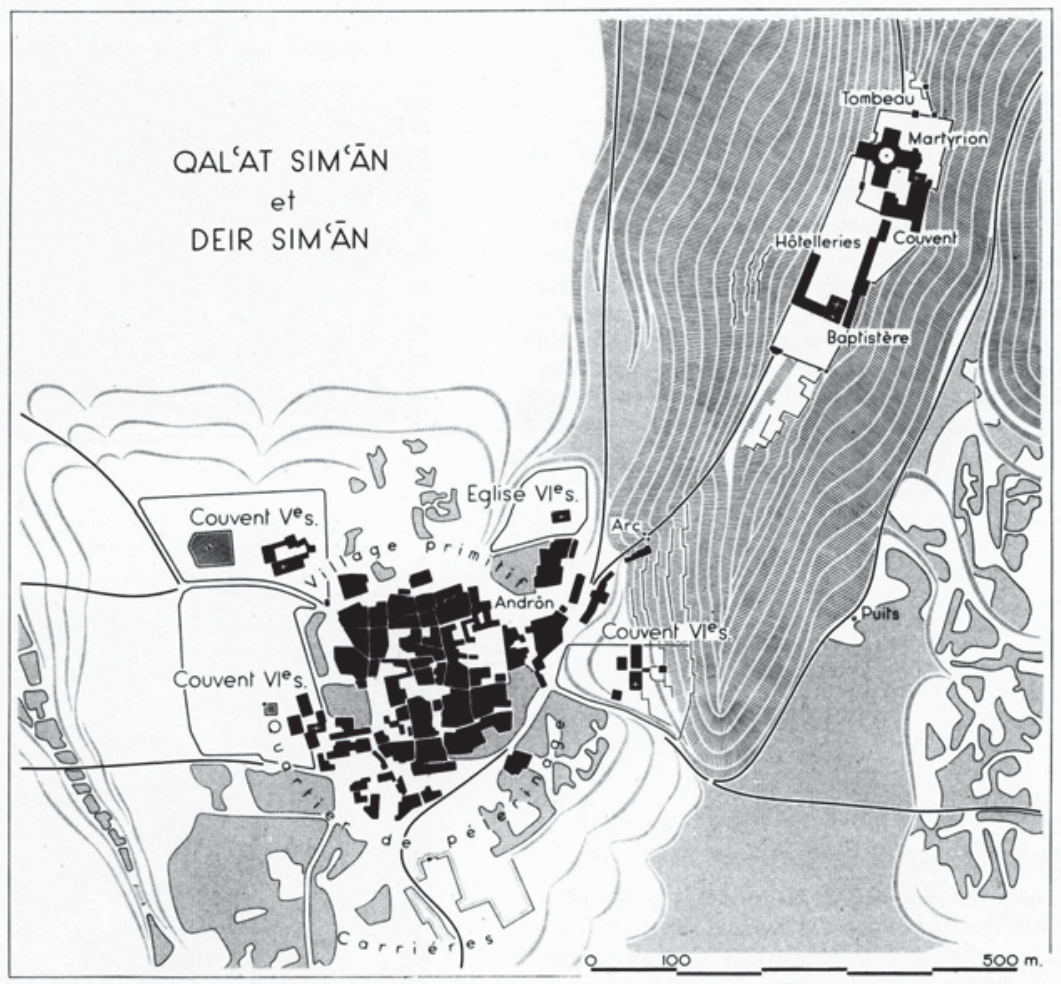

Fig. 2. Map of Telneshe (modern Deir Sim'an) and pilgrimage complex (Qal'at Sem'an). Simeon of Marimîn's pandocheion is located next to the 'Andron' on this map. [From Tchalenko, Villages antiques, vol. 2, pl. cxxxii.] 


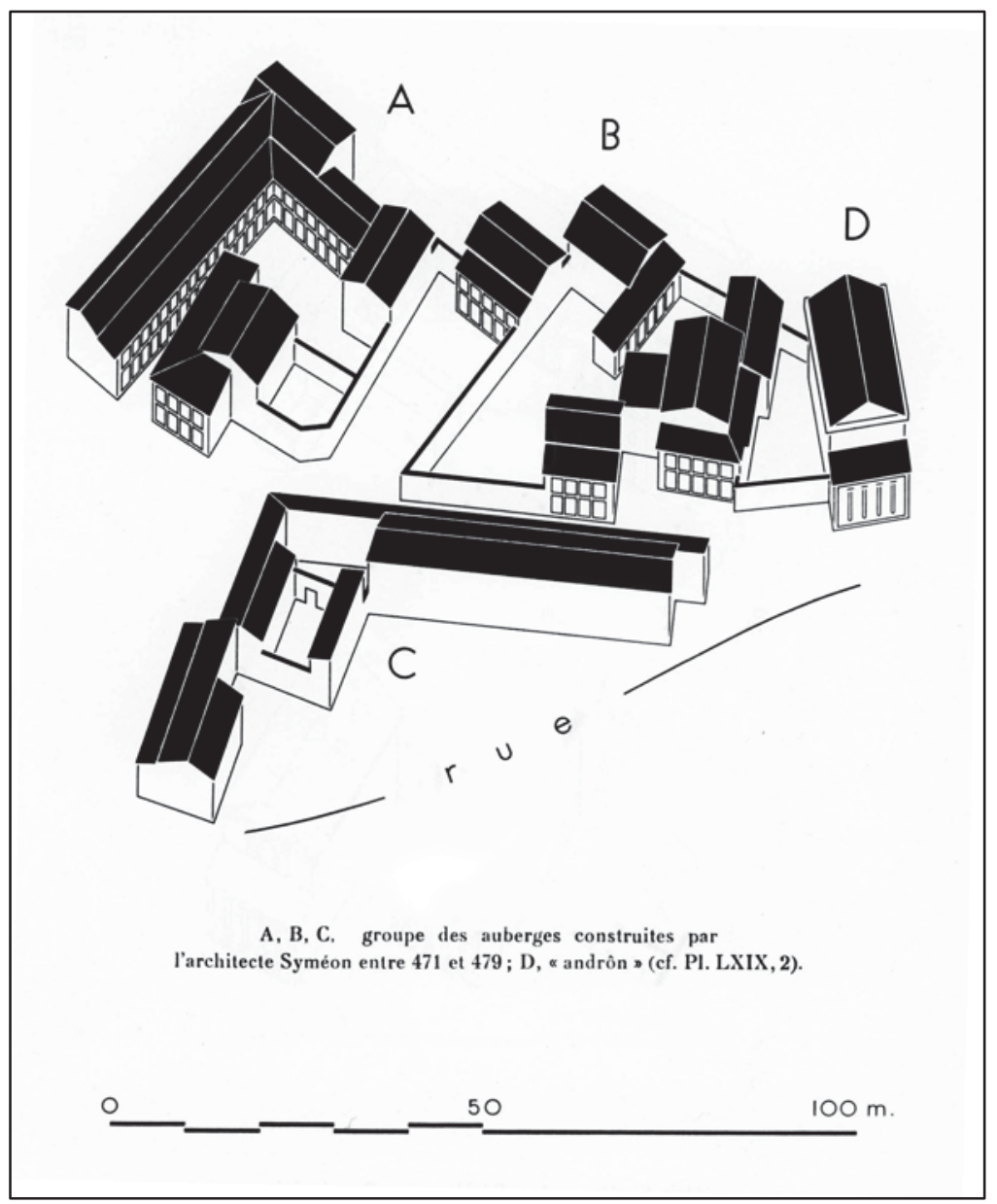

Fig. 3. Reconstruction of the pandocheion. Simeon of Marimin was responsible for sections A, B, and C. [From Tchalenko, Villages antiques, vol. 2, pl. lxviii.] 


\section{BIBLIOGRAPHY}

\section{Primary Sources}

Assemani, Stefano Evodio. Acta Sanctorum Martyrum Orientalium et Occidentalium: In Duas Partes Distributa. Adcedunt Acta S. Simeonis Stylitae. Omnia Nunc Primum ... E Bibliotheca ... Vaticana Prodeunt. Pars II. Romae: J. Collini, 1748.

Bedjan, Paul. Ed. Acta Martyrum et Sanctorum. Vol. 4. Parisiis and Lipsiae: Harrassowitz, 1890.

Bohas, Georges, René Lavenant †, Jean Reynard, Jean-Baptiste Yon, Dominique Gonnet, et al. Ed. and trans. Vie de Syméon le Stylite. Sources Chrétiennes. Paris: Editions du Cerf, forthcoming.

Brière, M. and F. Graffin. Ed. and trans. Homélie xxx. PO 36 (1974): 608-39.

Canivet, Pierre and Alice Leroy-Molinghen. Eds. and trans. Histoire Des Moines De Syrie: Histoire Philothée. Sources Chrétiennes 234 and 257. Paris: Éditions du Cerf, 1977.

Dawes, Elizabeth A. S. and Norman Hepburn Baynes. Trans. Three Byzantine Saints: Contemporary Biographies of St. Daniel the Stylite, St. Theodore of Sykeon, and St. John the Almsgiver. Oxford: B. Blackwell, 1948; reprint Crestwood, N.Y.: St. Vladimir's Seminary Press, 1996.

Doran, Robert. Ed. and trans. The Lives of Simeon Stylites. Cistercian Studies Series 112. Kalamazoo, Mich.: Cistercian Publications, 1992.

---. Stewards of the Poor: The Man of God, Rabbula, and Hiba in FifthCentury Edessa.Cistercian Studies Series 208. Kalamazoo, Mich.: Cistercian Publications, 2006.

Festugière, A. J. Ed. and trans. Vie de Théodore de Sykéôn. Vol. 1-2. Subsidia Hagiographica 48. Bruxelles: Soc. des Bollandistes, 1970.

Garitte, Gérard. Ed. and trans. Vies Géorgiennes de S. Syméon Stylite l'ancien et de S. Ephrem. Louvain: L. Durbecq, 1957. 
Harvey, Susan Ashbrook. Trans. "Jacob of Serug Homily on Simeon Stylite." In Ascetic Behavior in Greco-Roman Antiquity: A Sourcebook, ed. Vincent L. Wimbush. Minneapolis: Fortress Press, 1990.

Lent, Frederick. "The Life of St. Simeon Stylites: A Translation of the Syriac Text in Bedjan's Acta Martyrum et Sanctorum, Vol. iv." JAOS 35 (1915): 103-98.

Lietzmann, Hans, Heinrich Hilgenfeld, and Jena Lietzmann. Das Leben des Heiligen Symeon Stylites. TU. Leipzig: J. C. Hinrichs, 1908 .

\section{Secondary Sources}

Assemani, Giuseppe Simone. Bibliotheca Orientalis ClementinoVaticana: In Qua Manuscriptos Codices Syriacos, Arabicos, Persicos, Turcicos, Hebraicos, Samaritanos, Armenicos, Aethiopicos, Graecos, Aegyptiacos, Ibericos, \& Malabaricos, Jussu et Munificentia Clementis Xi, Pontificis Maximi, ex Oriente Conquisitos, Comparatos, Avectos, \& Bibliothecae Vaticanae Addictos. Romae: Typis Sacrae Congregationis de Propaganda Fide, 1719.

Assemani, Stefano Evodio and Joseph Simonius Assemani. Bibliothecae Apostolicae Vaticanae Codicum Manuscriptorum Catalogus in Tres Partes Distributus in Quarum Prima Orientales in Altera Graeci in Tertia Latini Italici Aliorumque Europaeorum Idiomatum Codices. Pt. 1, Vol. 3. Paris: Maisonneuve, 1756-1759.

Azpeitia, Johanne and Alain Desreumaux. "Deir Sim'ân, monastère nord-ouest: présentation de l'église; avec un appendice épigraphique; les inscriptions syriaques." TM 15 (2005): 37-66.

Bagnall, Roger S. Early Christian Books in Egypt. Princeton, N.J.: Princeton University Press, 2009.

Boero, Dina. "Promoting a Cult Site without Bodily Relics: Material Substances and Imagined Topography in the Syriac Life of Symeon the Stylite." In Religious Competition in the GrecoRoman World. Ed. Nathaniel P. DesRosiers and Lily C. Vuong. Atlanta: Society of Biblical Literature Press, forthcoming.

---. "Symeon and the Making of the Stylite." PhD diss., University of Southern California, forthcoming 2015. 
Brière, M. Introduction Générale aux Homélies de Sévère d'Antioche. PO 29 (1960): 7-72.

Brock, Sebastian P. The History of the Holy Mar Main with a Guide to the Persian Martyr Acts. Persian Martyr Acts in Syriac: Texts and Translation. Piscataway, NJ: Gorgias Press, 2008.

Butler, Howard Crosby and E. Baldwin Smith. Early Churches in Syria. Fourth to Seventh Centuries. PMAA. Amsterdam: Adolf M. Hakkert, 1929.

Cébeillac-Gervasoni, Mireille. "Les travaux publics à la fin de la république dans le Latium et la Campanie du Nord: la place de la classe dirigeante et des familles de notables." Cabiers du Centre Gustave Glotz 2 (1991): 189-213.

Chabot, Victor. "Antiquités de la Syrie du Nord." BCH 26 (1902): 160-208.

Constable, Olivia. Housing the Stranger in the Mediterranean World: Lodging, Trade, and Travel in Antiquity and the Middle Ages. Cambridge: Cambridge University Press, 2003.

Delehaye, Hippolyte. Les Saints Stylites. SubsHag 14. Bruxelles and Paris: Société des Bollandistes and A. Picard, 1923.

Doran, Robert. "Compositional Comments on the Syriac Versions of the Life of Simeon Stylites." AB 102 (1984): 35-48.

Festugière, A. J. Antioche païenne et chrétienne; Libanius, Chrysostome et les moines de Syrie. BEFAR, Fasc. 194. Paris: E. de Boccard, 1959.

Flusin, Bernard. "Syméon et les philologues ou la mort du stylite." In Les saints et leur sanctuaire à Byzance: textes, images et monuments, ed. Catherine Jolivet-Lévy, Michel Kaplan, and Jean-Pierre Sodini. Paris: Publications de la Sorbonne, 1993.

Haines-Eitzen, Kim. Guardians of Letters: Literacy, Power, and the Transmitters of Early Christian Literature. Oxford and New York: Oxford University Press, 2000.

Harvey, Susan Ashbrook. "The Sense of a Stylite: Perspectives on Simeon the Elder." VChr 42 (1988): 376-94. 
---. "The Stylite's Liturgy: Ritual and Religious Identity in Late Antiquity." JEChrSt 6:3 (1998): 523-39.

Hatch, William Henry Paine. An Album of Dated Syriac Manuscripts. Monumenta Palaeographica Vetera, 2d Ser. Boston: American Academy of Arts and Sciences, 1946.

Jalabert, Louis and René Mouterde. Inscriptions grecques et latines de la Syrie. Vol. 2-4. Paris: P. Geuthner, 1929.

Jarry, Jacques. "Nouvelles inscriptions de Syrie du Nord." ZPapEpig 47 (1982): 73-103.

Kaufmann, Carl Maria. Handbuch der altchristlichen Epigrapbik. Freiburg im Breisgau; St. Louis, Mo.: Herder, 1917.

Lane Fox, Robin. "The Life of Daniel." In Portraits: Biographical Representation in the Greek and Latin Literature of the Roman Empire, ed. M. J. Edwards and S. Swain. Oxford: Clarendon Press, 1997.

Le Bas, Philip and W. H. Waddington. Voyage archâeologique en Gráece et en Asie Mineure. Vol. 3, pt. 1. Paris: Firmin-Didot fráeres, fils et cie, 1870.

Leclercq, Henri. "Hôpitaux, hospices, hôtelleries." In Dictionnaire d'archéologie chrétienne et de liturgie, ed. Fernand Cabrol and Henri Leclercq. Paris: Letouzey et Ané, 1907.

Littmann, Enno. "Zur Topographie der Antiochene und Apamene." Zeitschrift fur Semitistik 1 (1922): 163-95.

Loosley, Emma. The Architecture and Liturgy of the Bema in Fourth- to Sixth-Century Syrian Churches. Texts and Studies in Eastern Christianity. Leiden: Brill, 2012.

Mango, Marlia Mundell. "Patrons and Scribes Indicated in Syriac Manuscripts, 411 to 800 AD." XVI. Internationaler Byzantinistenkongress. Akten II/4 = JÖBG 32:4 (1983): 3-12.

---. "Production of Syriac Manuscripts, 400-700." In Scritture, Libri e testi nelle aree provinciali di Bisanzio: atti del seminario di erice (18-25 Settembre 1988), ed. G. Cavallo, Giuseppe De Gregorio, and Marilena Maniaci. Spoleta: Centro italiano di studi sull'alto Medioevo, 1991. 
Mayer, Wendy and Pauline Allen. The Churches of Syrian Antioch (300$638 \mathrm{CE})$. Late Antique History and Religion 1. Leuven: Peeters, 2012.

Milson, David. "The Syrian Technites Markianos Kyris († 425 C.E.)." ZDPV 119: 2 (2003): 159-82.

Nöldeke, Theodor. Sketches from Eastern History. Trans. J. Sutherland Black. London and Edinburgh: A. and C. Black, 1892.

Ousterhout, Robert G. Master Builders of Byzantium. Princeton, N.J.: Princeton University Press, 1999.

Payne Smith, R., Etienne Quatremère, Georg Heinrich Bernstein, D. S. Margoliouth, and J. Payne Smith. Thesaurus Syriacus. Vols. 1-2. Oxonii: e typographeo Clarendoniano, 1879.

Peeters, Paul. Le tréfonds oriental de l'hagiographie Byzantine. SubsHag. Bruxelles: Société des Bollandistes, 1950.

Pleket, H. W. and R. S. Stroud. Eds. Supplementum Epigraphicum Graecum. Vol. XXVII. Alphen aan den Rijn, the Netherlands: Sijthoff \& Noordhoff, 1980.

Prentice, William Kelly. Greek and Latin Inscriptions. Publications of an American Archæological Expedition to Syria, 1899-1900. Vol. 3. New York: The Century co., 1908.

---. Greek and Latin Inscriptions. Publications of the Princeton University Archaeological Expedition to Syria in 1904, 1905 \& 1909. Div. III Sec. B. Leiden: Brill, 1922.

Segal, Judah Benzion. The Diacritical Point and the Accents in Syriac. London Oriental Series. London and New York: Oxford University Press, 1953.

Sivan, Hagith. "Pilgrimage, Monasticism, and the Emergence of Christian Palestine in the Fourth Century." In The Blessings of Pilgrimage, ed. Robert G. Ousterhout. Urbana: University of Illinois Press, 1990.

Sodini, Jean-Pierre and Jean-Luc Biscop. "Qal'at Sem'an and Deir Sem'an: naissance et développement d'un lieu de pèlerinage durant l'antiquité tardive." In Architecture Paléochrétienne, ed. J. M. Spieser. Gollion: Infolio, 2011. 
Tannous, Jack Boulos Victor. "Syria between Byzantium and Islam: Making Incommensurables Speak." PhD diss., Princeton University, 2010.

Tate, Georges. Les campagnes de la Syrie du nord du ïe au vïie siècle: un exemple d'expansion démographique et économique dans les campagnes à la fin de l'antiquité. Bibliothèque archéologique et historique t. 133. Paris: Libr. orientaliste P. Geuthner, 1992.

Tchalenko, George. Eglises syriennes à Bêma. Bibliothèque archéologique et historique \& Institut français d'archéologique $\mathrm{du}$ proche-orient. Paris: Librairie orientaliste P. Geuthner, 1990.

---. Villages antiques de la Syrie du nord; le massif du bélus à l'époque romaine. Vol. 1-3. Institut français d'archéologie de Beyrouth 1. Paris: P. Geuthner, 1953.

Torrey, Charles C. "The Letters of Simeon the Stylite." JAOS 20 (1899): 253-76.

Vööbus, Arthur. History of Asceticism in the Syrian Orient; a Contribution to the History of Culture in the Near East. Vol. 2. CSCO 197. Louvain: Secrétariat du CSCO, 1960.

Williams, Megan Hale. The Monk and the Book: Jerome and the Making of Christian Scholarship. Chicago: University of Chicago Press, 2006.

Wright, William. Catalogue of Syriac Manuscripts in the British Museum Acquired since the Year 1838. Vol. 1-3. London: Gilbert and Rivington Printers, 1870.

---. A Short History of Syriac Literature. London: A. and C. Black, 1894. 
